\title{
Sector collapses and large landslides on Late Pleistocene-Holocene volcanoes in Kamchatka, Russia
}

\author{
Vera V. Ponomareva *, Ivan V. Melekestsev, Oleg V. Dirksen \\ Institute of Volcanology and Seismology, Piip Blvd. 9, Petropavlovsk-Kamchatsky, 683006, Russia
}

Received 3 February 2005; accepted 10 April 2006

Available online 8 June 2006

\begin{abstract}
On Kamchatka, detailed geologic and geomorphologic mapping of young volcanic terrains and observations on historical eruptions reveal that landslides of various scales, from small $\left(0.001 \mathrm{~km}^{3}\right)$ to catastrophic (up to $20-30 \mathrm{~km}^{3}$ ), are widespread. Moreover, these processes are among the most effective and most rapid geomorphic agents. Of 30 recently active Kamchatka volcanoes, at least 18 have experienced sector collapses, some of them repetitively. The largest sector collapses identified so far on Kamchatka volcanoes, with volumes of $20-30 \mathrm{~km}^{3}$ of resulting debris-avalanche deposits, occurred at Shiveluch and Avachinsky volcanoes in the Late Pleistocene. During the last 10,000 yr the most voluminous sector collapses have occurred on extinct Kamen' $\left(4-6 \mathrm{~km}^{3}\right)$ and active Kambalny $\left(5-10 \mathrm{~km}^{3}\right)$ volcanoes. The largest number of repetitive debris avalanches $(>10$ during just the Holocene) has occurred at Shiveluch volcano. Landslides from the volcanoes cut by ring-faults of the large collapse calderas were ubiquitous. Large failures have happened on both mafic and silicic volcanoes, mostly related to volcanic activity. Orientation of collapse craters is controlled by local tectonic stress fields rather than regional fault systems.

Specific features of some debris avalanche deposits are toreva blocks - huge almost intact fragments of volcanic edifices involved in the failure; some have been erroneously mapped as individual volcanoes. One of the largest toreva blocks is Mt. Monastyr' $-\mathrm{a} \sim 2 \mathrm{~km}^{3}$ piece of Avachinsky Somma involved in a major sector collapse 30-40 ka BP.

Long-term forecast of sector collapses on Kliuchevskoi, Koriaksky, Young Cone of Avachinsky and some other volcanoes highlights the importance of closer studies of their structure and stability.

(C) 2006 Elsevier B.V. All rights reserved.
\end{abstract}

Keywords: volcano; sector collapse; landslide; debris avalanche; Kamchatka

\section{Geological background and previous studies}

The Kamchatka Peninsula, located along the northwestern border of the subducting Pacific plate (Fig. 1), is one of the most active volcanic and seismic regions of the world (Simkin and Siebert, 1994; Gorbatov et al., 1997). Kamchatka hosts about 30 active volcanoes and

\footnotetext{
* Corresponding author. Current address: Geological Institute Pyzhevsky per., 7 Moscow 119017, Russia. Fax: +7 0959530760.

E-mail address: ponomareva@ginras.ru (V.V. Ponomareva).
}

hundreds of monogenetic volcanic vents. Holocene volcanism in Kamchatka has been highly explosive (Melekestsev, 1980), and numerous tephra horizons interlayered with paleosols mantle the topography. Marker tephra layers associated with the largest Holocene eruptions have been mapped and dated (Braitseva et al., 1997a,b).

In southern Kamchatka, the volcanic arc runs parallel to the trench for about $500 \mathrm{~km}$ but then abruptly deviates to the northwest. North of this deviation is the most voluminous volcanic cluster of the arc, the Kliuchevskoi 


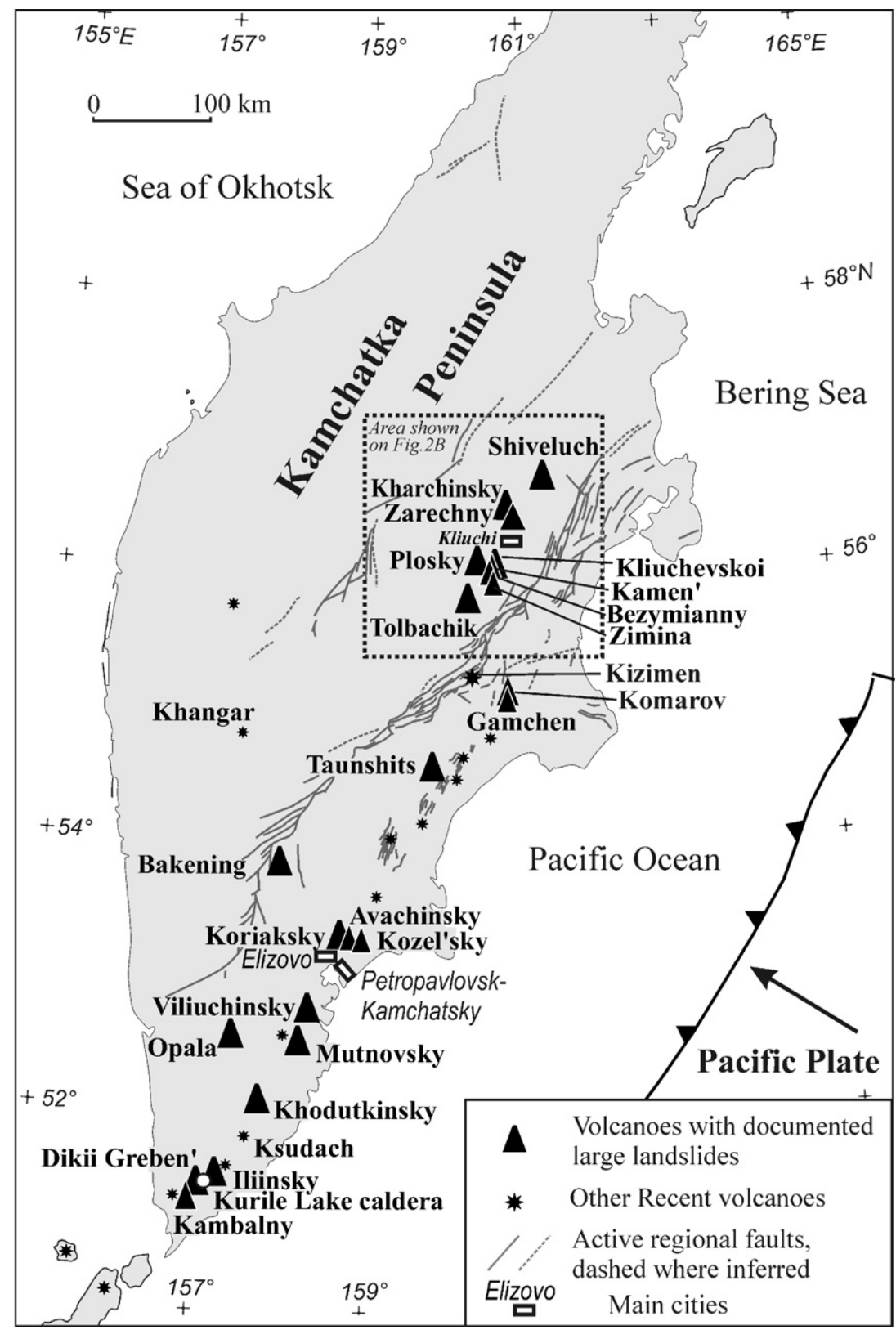

Fig. 1. Location of the volcanoes described in this paper. Regional fault systems according to Kozhurin, 2004. A dotted frame encloses an area shown on Fig. 2B and includes the Central Kamchatka Depression volcanoes.

group and Shiveluch, often referred to as the Central Kamchatka Depression (CKD) volcanoes (Figs. 1 and 2). The CKD cluster has the highest concentration of the giant (3-5 km a.s.1.) volcanic cones (Fig. 2A) and represents a departure from other Kamchatka volcanoes in terms of its geographic, tectonic and geochemical significance. These differences are likely related to the evolution of the Kamchatka-Aleutian junction (Yogodzinski et al., 2001; Park et al., 2002).
The first general overview of volcanic landslides in Kamchatka and on the Kurile Islands (Melekestsev and Braitseva, 1984) described many landslides but omitted two closely spaced historical collapses at the CKD volcanoes: 1956 Bezymianny and 1964 Shiveluch. The deposits of both collapses have been described in detail but at the time were thought to have originated from directed blasts (Gorshkov, 1959, 1963; Gorshkov and Bogoyavlenskaya, 1965; Piip and Markhinin, 1965; 

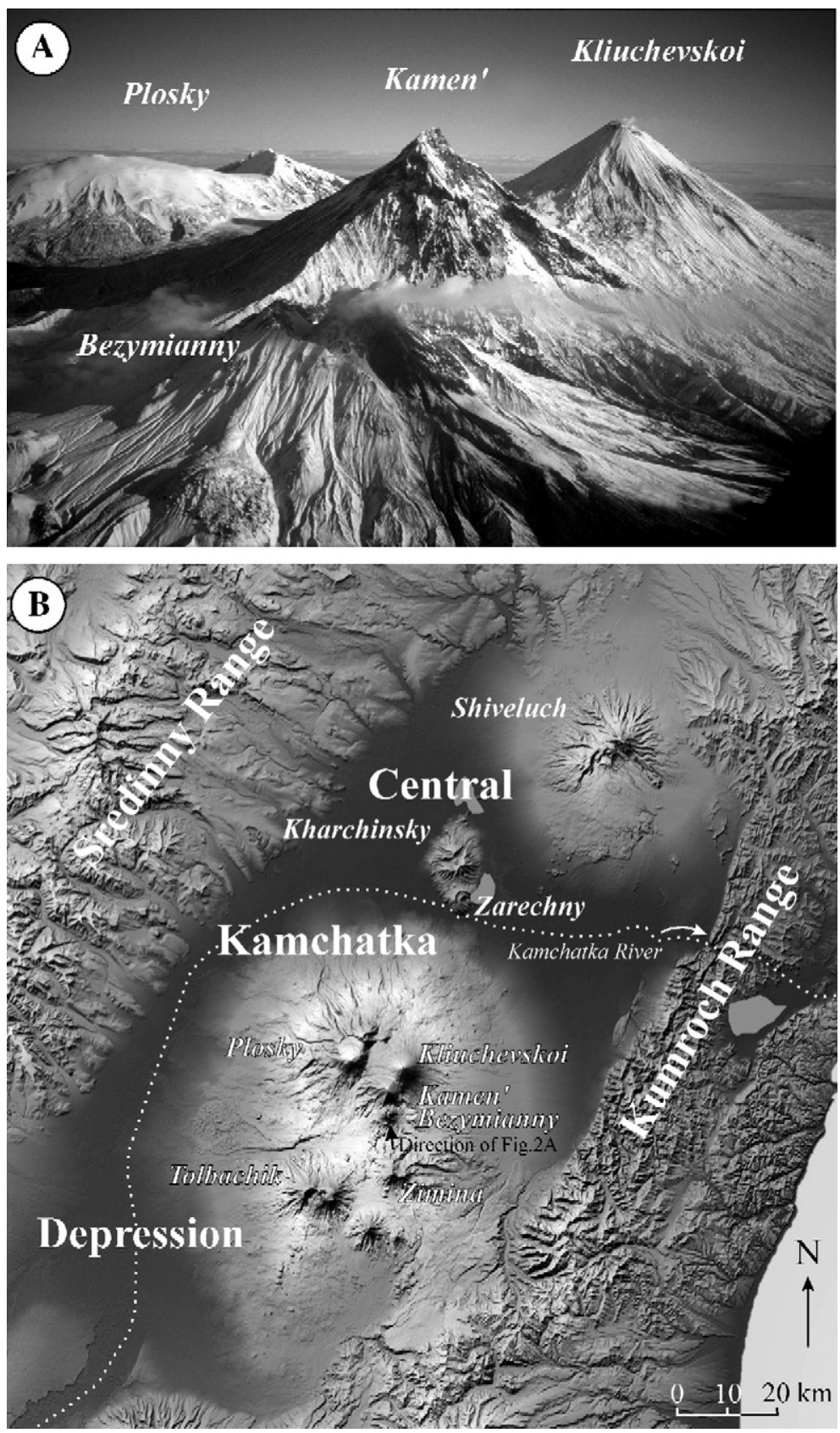

Fig. 2. A. Highest volcanoes of the Kliuchevskoi group: Kliuchevskoi, 4835 m a.s.1.; Kamen', 4585 m; Plosky massif with higher Plosky Blizhny, $4057 \mathrm{~m}$ (on the right), and flat Plosky Dalny (or Ushkovsky), $3903 \mathrm{~m}$; Bezymianny, $2869 \mathrm{~m}$ a.s.l. View from the south. B. Shaded SRTM elevation model showing the volcanoes of the Central Kamchatka Depression: Shiveluch, Kharchinsky and Zarechny north of the Kamchatka River, and Kliuchevskoi volcanic group — south of it. A part of the image released by NASA/JPL/NIMA.

Gorshkov and Dubik, 1970; Bogoyavlenskaya et al., 1985). Since then, both events have been reinterpreted as sector collapses and the resulting debris avalanche deposits re-examined (Belousov, 1995; Belousov and Belousova, 1998; Melekestsev, 2006). Other work on the CKD volcanoes includes studies of small-volume historical landslides on Kliuchevskoi (Dvigalo and Melekestsev, 2000), pre-historic collapses of Shiveluch (Ponomareva et al., 1998; Belousov et al., 1999) and brief mention of pre-historic collapses on Kamen', Tolbachik (Melekestsev and Braitseva, 1984), Kharchinsky and Zarechny volcanoes (Volynets et al., 1999). In 
the rest of Kamchatka, only Avachinsky, Bakening and Mutnovsky debris avalanche and landslide deposits have been documented earlier (Melekestsev and Braitseva, 1984; Melekestsev et al., 1992, 1999) although landslide craters have been identified on 22 volcanoes (Leonov, 1995).

The primary aim of this paper is to attract attention to Kamchatka volcanoes, which with the exception of a few of them, have been underrepresented in Englishlanguage literature. We describe major landslide and debris avalanche deposits on Kamchatka volcanoes, moving from north to south, with focus on previously undescribed cases. We include age, volume, and recurrence rate of landslides and consider causes and possible triggers. We pay special attention to toreva blocks - huge, almost-intact failed fragments of volcanic edifices (Reiche, 1937; Francis et al., 1985; Wadge et al., 1995).

Landslide craters and associated landslide and debris avalanche deposits have been first identified on largescale airphotos and space images and then examined in the field. Ages of the deposits have been determined based on their relationships with the earlier dated marker tephra layers and additional ${ }^{14} \mathrm{C}$ dates (Fig. 3). Interpretation of landslide and debris avalanche deposits in Kamchatka as well as in other regions, which experienced glaciation, should consider resemblance of some collapse features to glacial ones: on the space images some glacial cirques resemble collapse scars, and moraine deposits especially from alpine glaciers mimic rock avalanche deposits. Some of the Late Pleistocene toreva blocks might have changed their original topography due to glacial impact.

\section{Volcanoes of the Central Kamchatka depression}

Dominantly andesitic Shiveluch volcano (Figs. 1 $2 \mathrm{~B}, 4)$ is one of the most voluminous explosive centers of Kamchatka, with a magma discharge of about $36 \times 10^{6} \mathrm{t}$ per year, an order of magnitude higher than that typical of island arc volcanoes (Melekestsev et al., 1991). The Shiveluch edifice rises $\sim 3200 \mathrm{~m}$ above its surroundings. The volcano consists of the Late Pleistocene stratovolcano (Old Shiveluch), partly destroyed by a 9-km-wide collapse crater, which now encloses an active eruptive center (Young Shiveluch). Shiveluch activity during the Holocene has been characterized by plinian eruptions alternating with periods of dome growth and subsequent debris avalanches (Ponomareva et al., 1998, 2002).

A well-known plinian eruption of Young Shiveluch in 1964 was preceded by failure of its southern sector

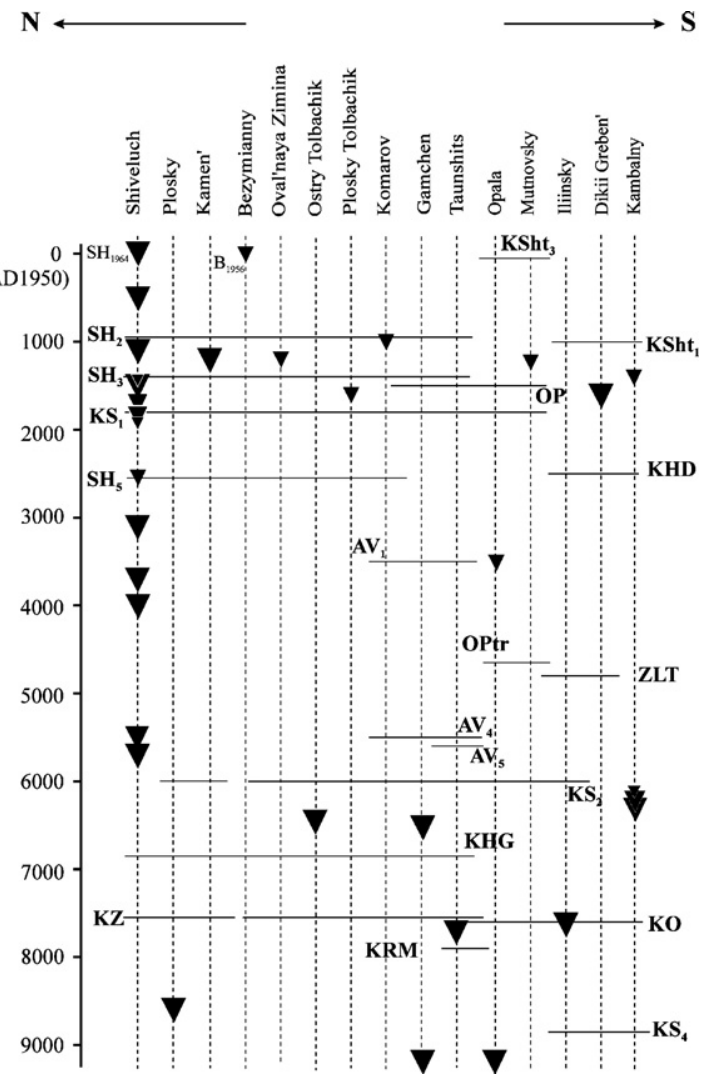

Fig. 3. Stratigraphic position of the dated Holocene debris avalanche and landslide deposits in relation to the regional marker tephra layers. Volcanoes are organized from north to south. Larger triangles show deposits with the volumes of $>1 \mathrm{~km}^{3}$; smaller ones $-0.1-1 \mathrm{~km}^{3}$. Smaller deposits are not shown. Codes and ages of marker tephra layers according to Braitseva et al. (1997a,b) with additions and corrections from Bazanova and Pevzner (2001) and Ponomareva et al. (2001, 2004). Marker tephra layers are from Shiveluch volcano $\left(\mathrm{SH}_{1964}, \mathrm{SH}_{2}, \mathrm{SH}_{3}, \mathrm{SH}_{5}\right)$, Ksudach caldera complex $\left(\mathrm{KSht}_{1}, \mathrm{KSht}_{3}\right.$, $\mathrm{KS}_{1}, \mathrm{KS}_{2}, \mathrm{KS}_{4}$ ), Barany Amphitheater crater on Opala volcano (OP), Avachinsky $\left(\mathrm{AV}_{1}, \mathrm{AV}_{4}, \mathrm{AV}_{5}\right)$, Khangar (KHG), Kizimen (KZ), Karymsky caldera (KRM), Chasha crater (OPtr), Khodutkinsky crater (KHD), Iliinsky volcano (ZLT), Kurile Lake caldera (KO).

(Belousov, 1995). The area covered by the 1964 debris avalanche deposits is about $98 \mathrm{~km}^{2}$, its volume about $1.5 \mathrm{~km}^{3}$, and its travel distance about $16 \mathrm{~km}$ (Table 1). A part of the material was displaced as three large toreva blocks which form up to $1.5 \mathrm{~km}$ long and $0.15 \mathrm{~km}$ high "stairs" immediately south of the collapse crater (Gorshkov and Dubik, 1970; Ponomareva et al., 1998; Belousov et al., 1999). The debris avalanche was not followed by a lateral blast, indicating the absence of a cryptodome in the volcanic edifice (Belousov, 1995). A lava dome has been growing in the collapse crater since 1980, occasionally producing pyroclastic density currents, landslides, and 


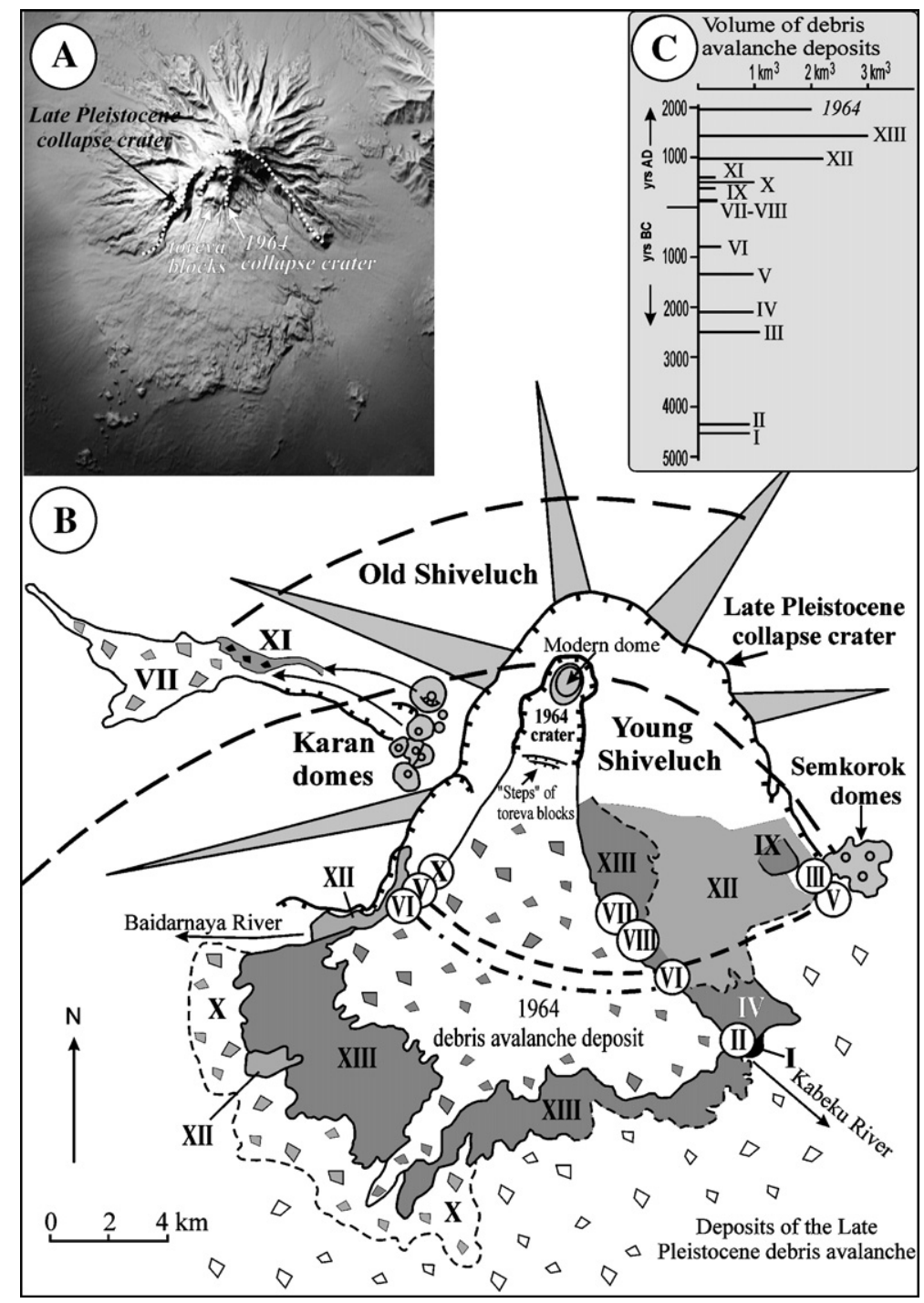

Fig. 4. Debris avalanche deposits at Shiveluch volcano. A - Shaded SRTM elevation model showing Shiveluch volcano. A part of the image released by NASA/JPL/NIMA. B - Schematic geological map of Shiveluch volcano. The Old Shiveluch edifice is shown with gray rays. The 9-km wide crater, open to the south, formed $>10 \mathrm{ka} \mathrm{BP}$ (most likely $\sim 30 \mathrm{ka} \mathrm{BP}$ ) as a result of a sector collapse; deposits of the resulting debris avalanche(s) are seen beyond the boundaries of the Holocene avalanches. Deposits of the Holocene debris avalanches are shown with various fillings. Deposits of debris avalanches II, III, V, VI, VII and VIII south of the volcano are buried under younger deposits and exposed only in the outcrops shown with the numbered circles. Presumed boundaries of the deposits of the avalanches V, VI and X are shown with dashed lines at the southern foot of the volcano. Thick dashed lines north of the 1964 crater show normal faults inferred from airphotos interpretation. C - Calendar ages of the collapse events and the volumes of the resulting debris avalanche deposits. Roman numbers correspond to those on the map. Holocene debris avalanche deposits, their numbers and ages are shown according to Ponomareva et al. (1998).

minor ash falls; some recent eruptions (e.g. in 2004) have been triggered by partial collapse of the growing dome (Dvigalo, 1984; Gorelchik et al., 1995; Khubunaya et al., 1995; Zharinov et al., 1995; Firstov et al., 1995; Fedotov et al., 2001; Ozerov and Demianchuk, 2004).

Twelve pre-historic debris avalanche deposits younger than $5700{ }^{14} \mathrm{C}$ yr BP were documented on the southern slope and two more on the western slope of Shiveluch at a distance of $\geq 7 \mathrm{~km}$ from the active vent (Fig. 4B, C; Table 1; Ponomareva et al., 1998). All Holocene collapses were followed by explosive eruptions, however, the largest plinian eruptions of Shiveluch were not associated with debris avalanches (Ponomareva et al., 1998). The travel distances of individual Holocene avalanches exceed $20 \mathrm{~km}$, and their 
Table 1

Ages and parameters of the debris avalanche deposits identified at Shiveluch volcano

\begin{tabular}{|c|c|c|c|c|c|c|c|c|}
\hline $\begin{array}{l}\text { Debris } \\
\text { avalanche }\end{array}$ & $\begin{array}{l}\text { Rounded }{ }^{14} \mathrm{C} \\
\text { ages }(\mathrm{yr} \mathrm{BP})\end{array}$ & $\begin{array}{l}\text { Approximate } \\
\text { calendar years }\end{array}$ & $\begin{array}{l}\text { Drop height } \\
(H, \mathrm{~km})\end{array}$ & $\begin{array}{l}\text { Maximum run-out } \\
(L, \mathrm{~km})\end{array}$ & $\begin{array}{l}H / L \\
\text { ratio }\end{array}$ & $\begin{array}{l}\text { Area } \\
\left(\mathrm{km}^{2}\right)\end{array}$ & $\begin{array}{l}\text { Volume } \\
\left(\mathrm{km}^{3}\right)\end{array}$ & Note \\
\hline XIV & & AD1964 & 2.3 & 16 & 0.14 & 98 & $\sim 2$ & Historical \\
\hline XIII & 500 & AD 1430 & 2.6 & 20 & 0.13 & $>200$ & $>3$ & $* 600$ \\
\hline XII & 1100 & AD970 & 2.6 & 18 & 0.14 & $>100$ & $\sim 2$ & $* 1000$ \\
\hline XI & 1450 & AD630 & 1 & 7 & 0.14 & 5 & $\sim 0.1$ & Western slope \\
\hline $\mathrm{X}$ & 1600 & $\mathrm{AD} 430$ & $2.6-3.1$ & 19 & $0.14-0.16$ & $<100$ & $\sim 1$ & $* 1600$ \\
\hline IX & 1700 & AD380 & $2.0-2.5$ & 9 & $0.22-0.28$ & $?$ & $?$ & \\
\hline VIII & 1850 & AD150-190 & $2.2-2.7$ & 9 & $0.24-0.3$ & $?$ & $?$ & $?$ \\
\hline VII & 1900 & $\mathrm{AD} 120$ & 1.5 & 14.5 & 0.10 & $<100$ & $<1$ & Western slope \\
\hline VI & 2550 & BC780 & $2.0-2.5$ & 11 & $0.18-0.23$ & $<100$ & $<1$ & $* 2600$ \\
\hline V & 3100 & BC1330 & $2.1-2.6$ & 11 & $0.19-0.24$ & $<100$ & $\sim 1$ & $* *$ \\
\hline IV & 3700 & BC2080 & $2.3-2.8$ & 14 & $0.16-0.20$ & $?$ & $?$ & $* 3700$ \\
\hline III & 4000 & $\mathrm{BC} 2490$ & $2.1-2.6$ & $>10$ & $0.21-0.26$ & $?$ & $?$ & $?$ \\
\hline II & 5500 & $\mathrm{BC} 4350$ & $2.3-2.8$ & 14 & $0.16-0.20$ & $?$ & $?$ & \\
\hline I & 5700 & BC4530 & $2.3-2.8$ & 15 & $0.15-0.19$ & $?$ & $?$ & $* 5700$ \\
\hline- & Pre-Holocene & - & 3.3 & 32 & 0.10 & 400 & 30 & $*_{10000}$ \\
\hline
\end{tabular}

Note: Holocene debris avalanche deposits, their numbers and ages according to Ponomareva et al. (1998) with minor later corrections. Question mark in the last column indicates the deposits measured in only one section. Ages in the last column marked with an asterisk (*) show the debris avalanche deposits identified by Belousov et al. (1999). Double asterisk (**) indicates a deposit documented by Belousov et al. (1999) in Baidarnaya valley but correlated to an older unit with an age of $3700 \mathrm{yr}$ BP in Kabeku valley.

volumes reach $3 \mathrm{~km}^{3}$ (Table 1). The parts of avalanche deposits (I, IV, IX, X, XII and XIII) not obscured by younger deposits display a typical hummocky topography. The same is true for debris avalanche deposits VII and XI at the western slope, associated with the activity of the Karan flank domes (Fig. 4B). Deposits of avalanches II, III, V-VIII at the southern slope of the volcano are completely buried under younger volcanic products but in outcrops exhibit typical "block facies", in many cases underlain by "mixed facies" (as in Glicken, 1986; Belousov et al., 1999) (see numbered circles Fig. 4B). Belousov et al. (1999) documented fewer debris avalanche deposits on the southern slope, specifically the largest ones from our list (Table 1). Considering high growth rate of a modern dome and overall high magma discharge during the last 2000 years (Ponomareva et al., 2002), we are sure that the real number of the collapse events at Shiveluch volcano is even larger than currently identified.

Multiple collapses of Shiveluch have been explained by high magma supply rate and repetitive dome formation (Ponomareva et al., 1998). In addition, various facies of the debris avalanche deposits, as well as features of their surface, have been examined in detail, and the high frequency of collapses has been explained by high viscosity and high water content of the ascending magma (Belousov et al., 1999). The collapses were probably triggered by intrusion of viscous magma beneath the summit domes and related seismicity (Belousov et al., 1999; Melekestsev, 2006).

The oldest exposed Shiveluch debris-avalanche deposit is pre-Holocene in age and is the most enigmatic. It forms a $\sim 400 \mathrm{~km}^{2}$ apron at the southern foot of the volcano with hummocks up to $130 \mathrm{~m}$ high (Fig. 4A, B). It is believed to have resulted from a single event which formed a $9 \mathrm{~km}$-wide crater $\sim 30,000{ }^{14} \mathrm{C} \mathrm{yr}$ BP (Melekestsev et al., 1991; Braitseva et al., 1995) or $\sim 10,000$ yr BP (Belousov et al., 1999). The aspect of the crater, open to the south, was controlled by a system of normal faults with vertical displacements of $\sim 500 \mathrm{~m}$ (Fig. 4B; Melekestsev et al., 1974). This large sector collapse was likely triggered by reactivation of basement faults as in analogue modeling by Vidal and Merle (2000). The resulting crater is unusually wide and no traces of significant eruptive activity related to this event have been found. The crater should have existed before the 23-24 kyr BP last glacial maximum and would have been the accumulation area for an extensive glacier that spread to the south for $50 \mathrm{~km}, \sim 20 \mathrm{~km}$ farther than did the glaciers on the northern slope of the volcano (Melekestsev et al., 1991). In Kamchatka, preHolocene collapse(s) on Shiveluch are matched in scale only by Late Pleistocene collapses of Avachinsky volcano (see below). Worldwide most reported subaerial collapses of similar volumes also occurred in Late Pleistocene (Siebert, 1996; Siebert et al., 2004), while Holocene collapses tend to be under $10 \mathrm{~km}^{3}$ (McGuire, 1996). 


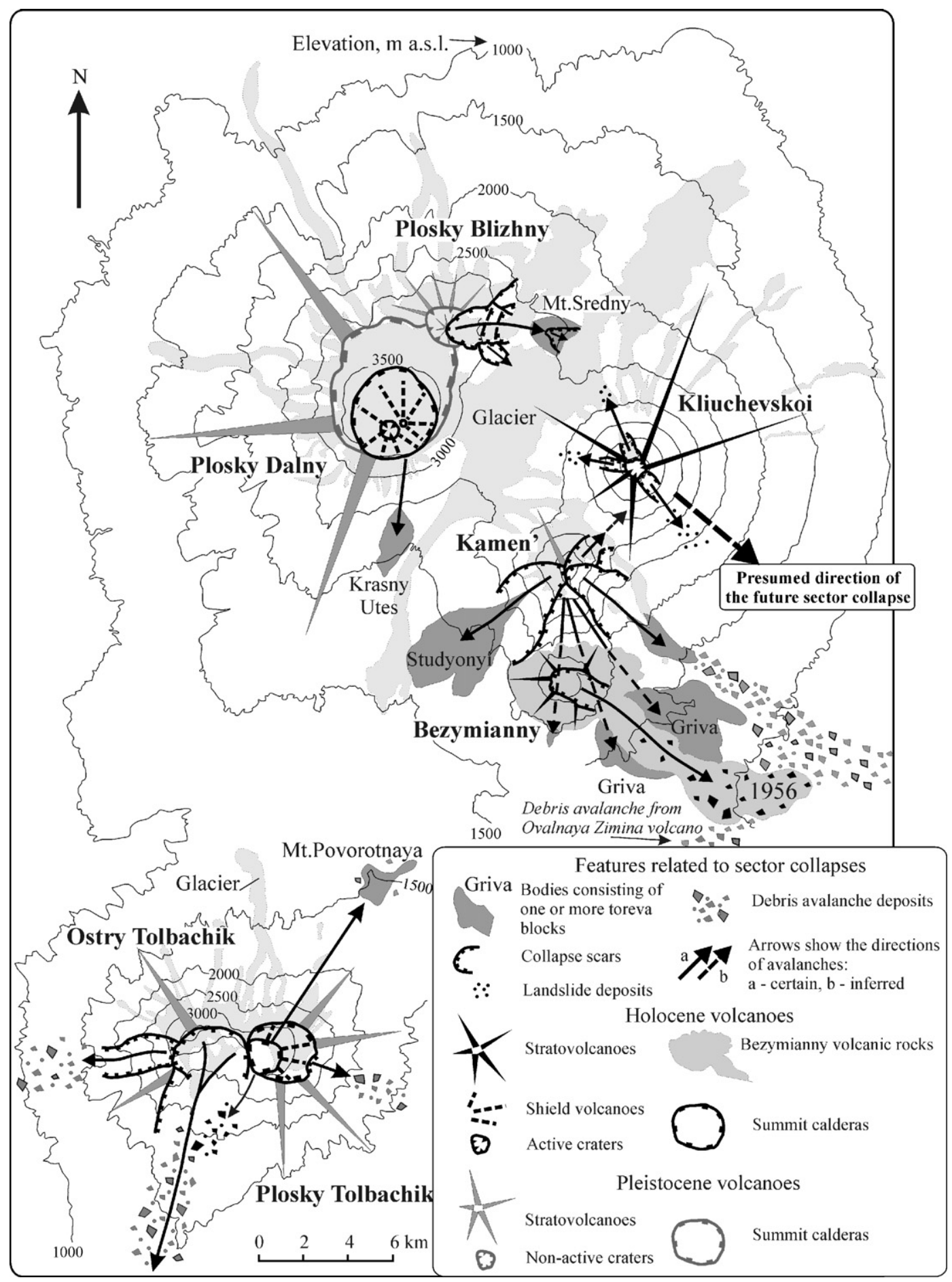

Fig. 5. Main debris avalanche deposits and toreva blocks on the volcanoes of the Kliuchevskoi group.

The northwest sector of extinct Kharchinsky volcano $\left(8-10 \mathrm{~km}^{3}\right)$ was also displaced most likely in the Late Pleistocene (Fig. 2B; Volynets et al., 1999). Extinct Zarechny volcano, bordering Kharchinsky to the south, has experienced at least two major collapses to southeast, both in Late Pleistocene, based on its well expressed collapse craters (Fig. 2B). The first collapse has removed $6-8 \mathrm{~km}^{3}$ and the second one $0.5-0.7 \mathrm{~km}^{3}$ 
Table 2

Debris avalanche and smaller landslide deposits at the Kliuchevskoi group volcanoes

\begin{tabular}{|c|c|c|c|c|c|}
\hline Volcano & $\begin{array}{l}\text { Volume } \\
\left(\mathrm{km}^{3}\right)\end{array}$ & $\begin{array}{l}\text { Drop } \\
\text { height } \\
(H, \mathrm{~km})\end{array}$ & $\begin{array}{l}\text { Runout } \\
(L, \mathrm{~km})\end{array}$ & $\begin{array}{l}H / L \\
\text { ratio }\end{array}$ & Date/age \\
\hline $\begin{array}{l}\text { Kliuchevskoi } \\
\text { (Kozyrevsky } \\
\text { chute) }\end{array}$ & 0.06 & $\sim 2$ & 2.5 & 0.8 & 02.12 .1985 \\
\hline $\begin{array}{l}\text { Kliuchevskoi } \\
\text { (Krestovsky } \\
\text { chute) }\end{array}$ & 0.05 & $\sim 2$ & $3.5-4$ & $0.57-0.5$ & 01.01 .1945 \\
\hline Kamen’' & $4-6$ & 4.4 & $>30$ & $<0.15$ & $\begin{array}{l}1200 \text { yr BP } \\
\left({ }^{14} \mathrm{C}\right)\end{array}$ \\
\hline Bezymianny & 0.8 & 2.6 & $17-18$ & $0.15-0.14$ & 30.03 .1956 \\
\hline $\begin{array}{r}\text { Ovalnaya } \\
\text { Zimina }\end{array}$ & $0.3-0.5$ & 2.6 & $>10$ & $<0.26$ & The same \\
\hline $\begin{array}{l}\text { Ostry } \\
\text { Tolbachik }\end{array}$ & $3-4$ & $>3$ & $>10$ & $<0.30$ & $\begin{array}{l}6500 \text { yr BP } \\
\left({ }^{14} \mathrm{C}\right)\end{array}$ \\
\hline
\end{tabular}

Note. Parameters of other debris avalanche deposits shown on Fig. 5 have not been determined due to poor exposure.

of the edifice (Volynets et al., 1999). The corresponding deposits are overlain by younger glacial and river sediments. Zarechny and Kharchinsky volcanoes have also experienced at least 11 smaller landslides $(0.001-$ $0.2 \mathrm{~km}^{3}$ ), most likely in the Late Pleistocene (Volynets et al., 1999). It is not known whether any of them were accompanied by eruptions.

The Kliuchevskoi volcanic group consists of active Kliuchevskoi, Bezymianny, Plosky Dalny and Plosky Tolbachik volcanoes as well as ten older, large eruptive centers and numerous small vents (Figs. 2 and 5). All the high volcanoes of Kliuchevskoi group were constructed during the Late Pleistocene or the Holocene (Melekestsev et al., 1974; Braitseva et al., 1995). The group's vigorous magma output during the Holocene accounts for more than half of Kamchatka's volcanic activity (Melekestsev, 1980).

All volcanoes in this group have experienced landslides, and the largest have produced debris avalanches and toreva blocks (Fig. 5; Tables 2 and 3). Collapse craters and associated deposits have been identified on large-scale airphotos and space images; most of them have been also mapped in the field. As already noted, the most famous historic collapse happened on andesitic Bezymianny volcano in 1956 and was followed by a lateral blast and plinian eruption. The sequence of events on Mount St. Helens in 1980 was similar. (Bogoyavlenskaya et al., 1985; Glicken, 1986). The sector collapse was caused by intrusion of a cryptodome into the edifice and related seismicity (Belousov, 1996). Since 1956, Novy dome has been growing inside the collapse crater. On June 30, 1985, a large $\left(\sim 0.05 \mathrm{~km}^{3}\right)$ landslide from the dome triggered an explosive eruption (Melekestsev, 2006).

Only $\sim 60 \%$ of the present cone of extinct Kamen' volcano retains its original topography, the rest of the edifice having been destroyed by multiple collapses with formation of debris avalanche deposits and toreva blocks (Figs. 2 and 5; Tables 2 and 3). A lower part of its southern collapse crater hosts Bezymianny volcano, deposits of which overlie huge blocks of slightly cemented volcanic breccia named Griva (Figs. 5 and 6). These blocks, as well as those forming Studyonyi, retain original layering and represent fragments of a volcanic cone. Similar breccia outcrops in the collapse craters on the Kamen' edifice. We presume that both Griva and Studyonyi were removed from Kamen' in the Late Pleistocene and are the only remnants of the debris avalanche deposits now buried under younger volcanic products.

The most recent of Kamen's collapses $(\sim 1200 \mathrm{yr}$ $\mathrm{BP})$ produced a giant avalanche $\left(4-6 \mathrm{~km}^{3}\right)$, the deposits of which are sandwiched between Bezymianny ignimbrite and tephra units (Braitseva et al., 1991). This stratigraphy suggests that the collapse from Kamen' coincided in time with strong eruptive activity of Bezymianny and was likely triggered by earthquakes, which accompanied Bezymianny eruptions. About the same time, $\sim 1200$ yr BP, a smaller collapse (0.3-

Table 3

Large toreva blocks at the Kliuchevskoi group volcanoes

\begin{tabular}{|c|c|c|c|c|c|c|}
\hline Name & Volcano & $\begin{array}{l}\text { Volume } \\
\left(\mathrm{km}^{3}\right)\end{array}$ & $\begin{array}{l}\text { Drop height } \\
(\mathrm{km})\end{array}$ & $\begin{array}{l}\text { Runout } \\
(\mathrm{km})\end{array}$ & Age & Note \\
\hline Mt. Sredny & Plosky Blizhny & $\sim 1$ & $\sim 1.8$ & $4.5-5$ & 8600 yr BP $\left({ }^{14} \mathrm{C}\right) ?$ & 1 block \\
\hline Krasny Utes & Plosky Dalny & $\sim 1$ & $\sim 2$ & $\sim 6$ & Late Pleistocene & 1 block \\
\hline Griva & Kamen’ & $8-10$ & $2-2.5$ & $6-8$ & Late Pleistocene & $\begin{array}{l}\text { Composite body consisting } \\
\text { of 5-6 individual blocks }\end{array}$ \\
\hline Studyonyi & Kamen' & $1.5-2$ & $1-1.5$ & $2-3$ & Late Pleistocene & $\begin{array}{l}\text { Composite body consisting } \\
\text { of } 3-4 \text { individual blocks }\end{array}$ \\
\hline Mt. Povorotnaya & Plosky Tolbachik & $0.4-0.5$ & $1.7-1.8$ & $\sim 8$ & 6500 yr BP $\left({ }^{14} \mathrm{C}\right) ?$ & $\begin{array}{l}\text { Composite body consisting } \\
\text { of } \geq 3 \text { individual blocks }\end{array}$ \\
\hline
\end{tabular}



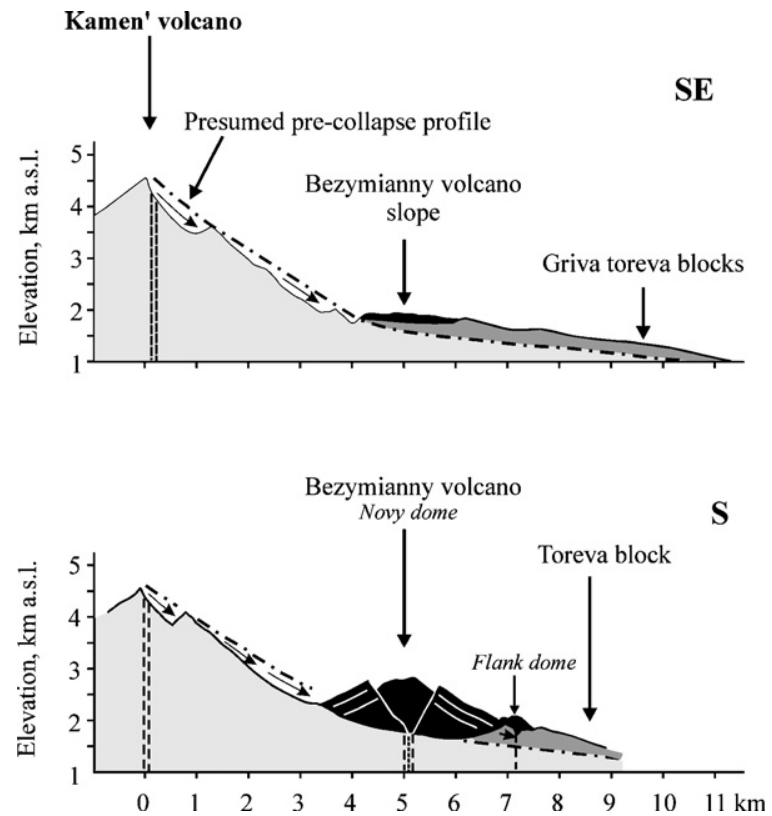

Fig. 6. Relationship of Holocene Bezymianny volcano with large blocks derived from the extinct Kamen' volcano. Presumed position of magma conduits is shown with dashed lines.

$0.5 \mathrm{~km}^{3}$ ) occurred on neighbouring extinct Ovalnaya Zimina volcano (Melekestsev and Braitseva, 1984).

Sredny, a $\sim 2 \mathrm{~km}^{3}$ conic mountain between giant Kliuchevskoi and Plosky volcanoes, earlier mapped as an individual volcano (Fig. 7A, B; Piip, 1956), was once a summit of Plosky Blizhny volcano (4057 a.s.1.) and was displaced likely during the caldera collapse on adjacent Plosky Dalny volcano $\sim 8600{ }^{14} \mathrm{C}$ yr BP (Braitseva et al., 1995). Judging from the position of the flank vents which drained the magma before the caldera collapse (Melekestsev et al., 1974), a magma-conducting fissure zone crossed Plosky Blizhny volcano and undermined it. Mt. Sredny, in its turn, hosts a collapse scar and was probably a part of a debris avalanche deposit now buried under Erman glacier (Fig. 7B). Mt. Sredny rocks are similar in composition to Plosky Blizhny ones (Tatiana Churikova, pers. comm., 2004). Krasnyi Utes (Fig. 5) likely may be interpreted as a toreva block: it retains originally layered lava and breccia similar to that composing Plosky Dalny slope (B.V. Ivanov, pers. comm., 2004).

Mt. Povorotnaya on the northeast slope of Plosky Tolbachik volcano (Fig. 5) consists of several large fragments each composed of stratified lava and breccia (Table 3). It is surrounded by recent lavas, which probably buried the related debris avalanche deposits. Collapses on both Ostry and Plosky Tolbachik volcanoes could have accompanied formation of subsequent calderas on Plosky Tolbachik (Melekestsev and Braitseva, 1984).

The almost perfectly shaped $4800 \mathrm{~m}$ high cone of Kliuchevskoi, the most active and productive Kamchatka volcano (Melekestsev, 1980), has also been affected by landslides, albeit on a smaller scale. This dominantly pyroclastic cone is sitting on the $1700 \mathrm{~m}$ high slope of Kamen'. Its height above the surroundings varies from $4800 \mathrm{~m}$ in the eastern sector to $2200 \mathrm{~m}$ in the northwestern and $1600 \mathrm{~m}$ in southwestern sectors, where it is buttressed by older volcanic edifices (Fig. 5). Three large (up to $1.5 \mathrm{~km}$ wide and 3-4 km long) chutes extend down the volcano's slopes radially from the summit crater (Fig. 7C, D) showing the direction of pre-historic landslides. During the 1984-87 summit eruption fresh lava flowed down the chutes; one flow collapsed, producing a rockslide of $0.006 \mathrm{~km}^{3}$ down to a glacier and triggering a number of phreatic explosions and a 30-km-long lahar (Dvigalo and Melekestsev, 2000). A larger rockslide $\left(\sim 0.05 \mathrm{~km}^{3}\right)$ occurred during the 1945 eruption (Dvigalo and Melekestsev, 2000; Melekestsev, 2006). Gullies on the foot of Kliuchevskoi exhibit multiple debris fans from older similar events.

The common occurrence of collapse events in the Kliuchevskoi group is associated with high volcanic productivity and volcanic seismicity. These volcanoes grew very fast compared to non-volcanic mountains of the same height. Composed of heterogeneous rocks including frozen layers of loose debris and ice lenses, they host extensive glaciers and are prone to active erosion. Kliuchevskoi volcano is likely a next candidate for a large collapse (Melekestsev and Braitseva, 1984). Its high edifice is strongly asymmetric, with steep (up to $35-37^{\circ}$ ) slopes; the cone is dissected by faults and ringfractures and experiences strong earthquakes. The most probable direction of the future large collapse is to south-east (Fig. 5) since this sector of the volcano is characterized by rapid tectonic subsidence (Melekestsev et al., 1974) and hosts multiple fresh faults.

\section{Eastern Kamchatka}

The Gamchen volcanic range is a traditional name for a volcanic range with an overall north-south orientation, which contains at least three Holocene volcanoes (Vysoky, $2153 \mathrm{~m}$ a.s.1., Komarov, $2050 \mathrm{~m}$, and Barany, $2320 \mathrm{~m}$ ) and several more of Late Pleistocene age including Gamchen (Fig. 8). Komarov volcano hosts a number of active solfatara fields (Fedotov and Masurenkov, 1991); its summit rocks are strongly altered, likely contributing to weakness of this rather small edifice. The western sector of the volcano 

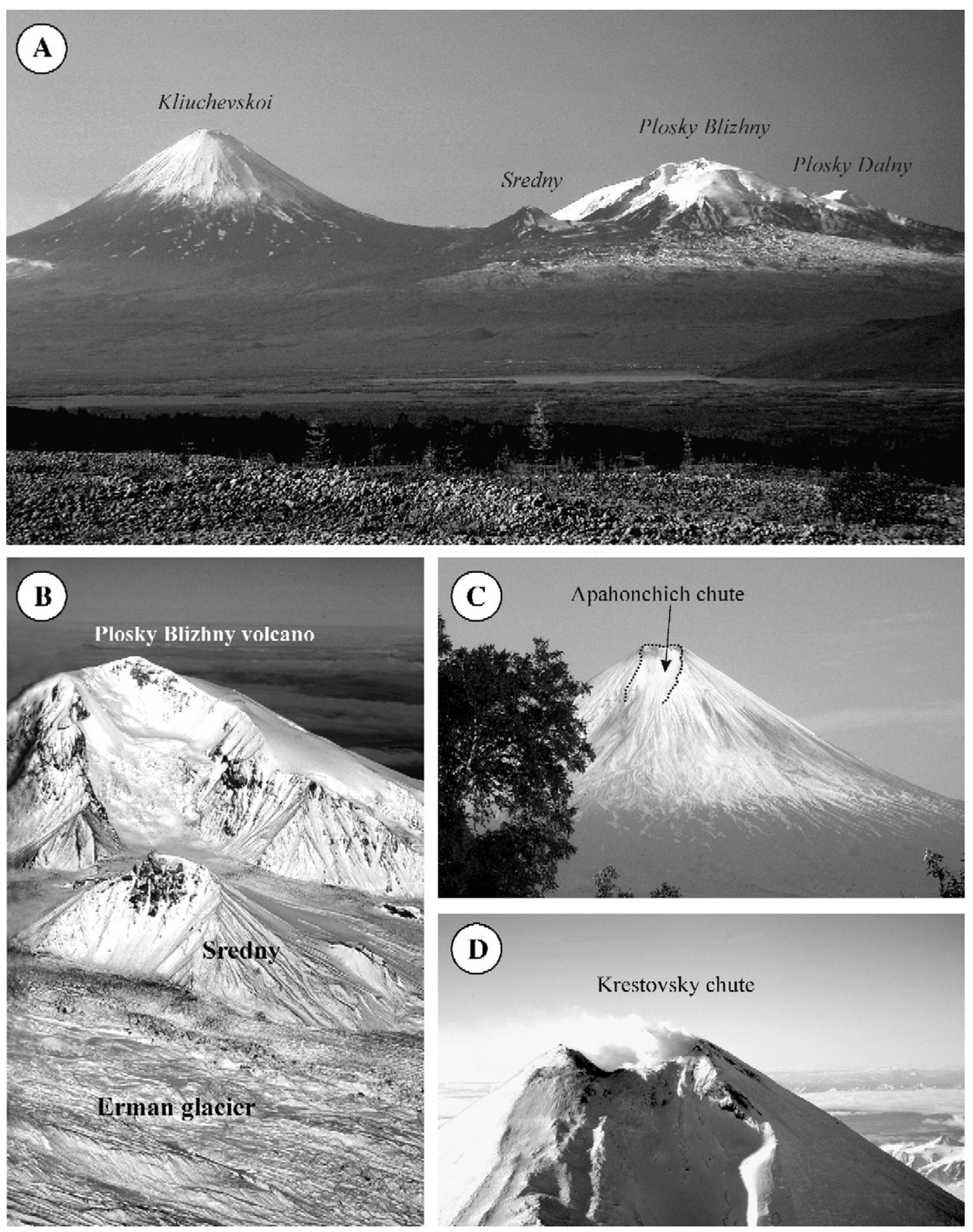

Fig. 7. Collapse related features on Kliuchevskoi group volcanoes. A - A classic view of the Kliuchevskoi group from the north. Small cone between giant Kliuchevskoi and Plosky volcanoes has been usually referred to as Sredny volcano (e.g. Piip, 1956). B — In fact, its topography and rocks composition suggest that Sredny is a toreva block displaced from Plosky Blizhny volcano. C-D - chutes on the summit part of the Kliuchevskoi cone: $\mathrm{C}$ - southeastern slope, D - NNW slope.

collapsed 1000 yr BP based on tephrochronological evidence; resulting landslide and lahar deposits are composed of altered rocks. Gamchen volcano per se consists of three Late Pleistocene cones and one
Holocene cone (Fig. 8). The Holocene cone Barany started to form $\sim 3600{ }^{14} \mathrm{C}$ years $\mathrm{BP}$ as evidenced by the stratigraphic position of its initial cinders directly below $\mathrm{AV}_{1}$ marker tephra $\left(3500{ }^{14} \mathrm{C}\right.$ years $\left.\mathrm{BP}\right)$ from 


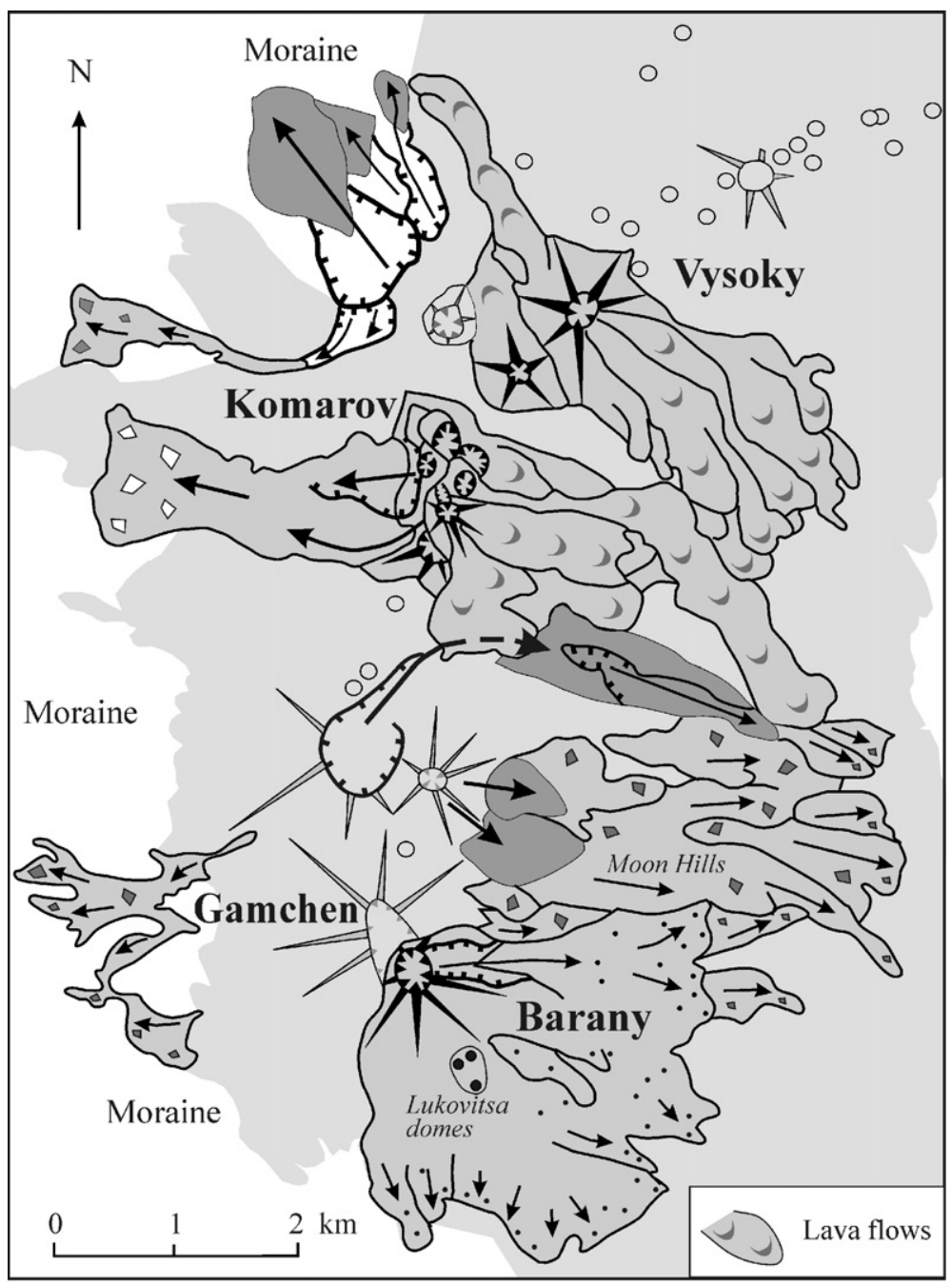

Fig. 8. Collapse related features on Gamchen volcanic ridge. The lightest gray field shows Late Pleistocene volcanic rocks, darker filling is for the Holocene deposits, the darkest filling is for toreva blocks. Late Pleistocene volcanoes are shown with light-gray stars and circles (the latter - for monogenetic vents), Holocene ones - with black stars and circles. Black dots show scoria avalanches on Barany cone. White-filled debris show clay-rich debris avalanche from Komarov volcano. Arrows indicate the direction of mass movement. Other symbols as in Fig. 5.

Avachinsky volcano (Braitseva et al., 1997b). The basaltic andesitic cone formed in several spurts of activity between 3600 and $3000{ }^{14} \mathrm{C}$ years BP. Landslides and scoria avalanches accompanied cone formation (Fig. 8). The high Late Pleistocene cones of the Gamchen massif (each $\sim 2500 \mathrm{~m}$ a.s.1.) experienced several sector collapses, at least two of them in the first half of the Holocene. Debris avalanche deposits form a field of hummocky topography ("Moon Hills") on the eastern slope of the volcano; a minor deposit is also located on its western slope (Fig. 8). Most of these deposits have earlier been mapped as lava flows (Fedotov and Masurenkov, 1991). Two hills at the eastern foot of the volcano have been mapped as extrusive domes (Fedotov and Masurenkov, 1991), but we interpret these as toreva blocks from one of the debris avalanche units based on their structure and lithologic similarity to the main edifice (Churikova et al., 2001). A large block between Gamchen massif and Komarov volcano likely originated from the present icefilled crater of the northern cone of the Gamchen massif (Fig. 8); however, this block needs further examination. It is not known whether Pleistocene collapses from Gamchen were accompanied by any eruptions; Holocene collapses definitely were not.

Taunshits volcano (elevation $2353 \mathrm{~m}$ a.s.l., Fig. 9A) dates back to the Late Pleistocene when a large tuya pedestal was formed (Melekestsev et al., 1974; Leonov 

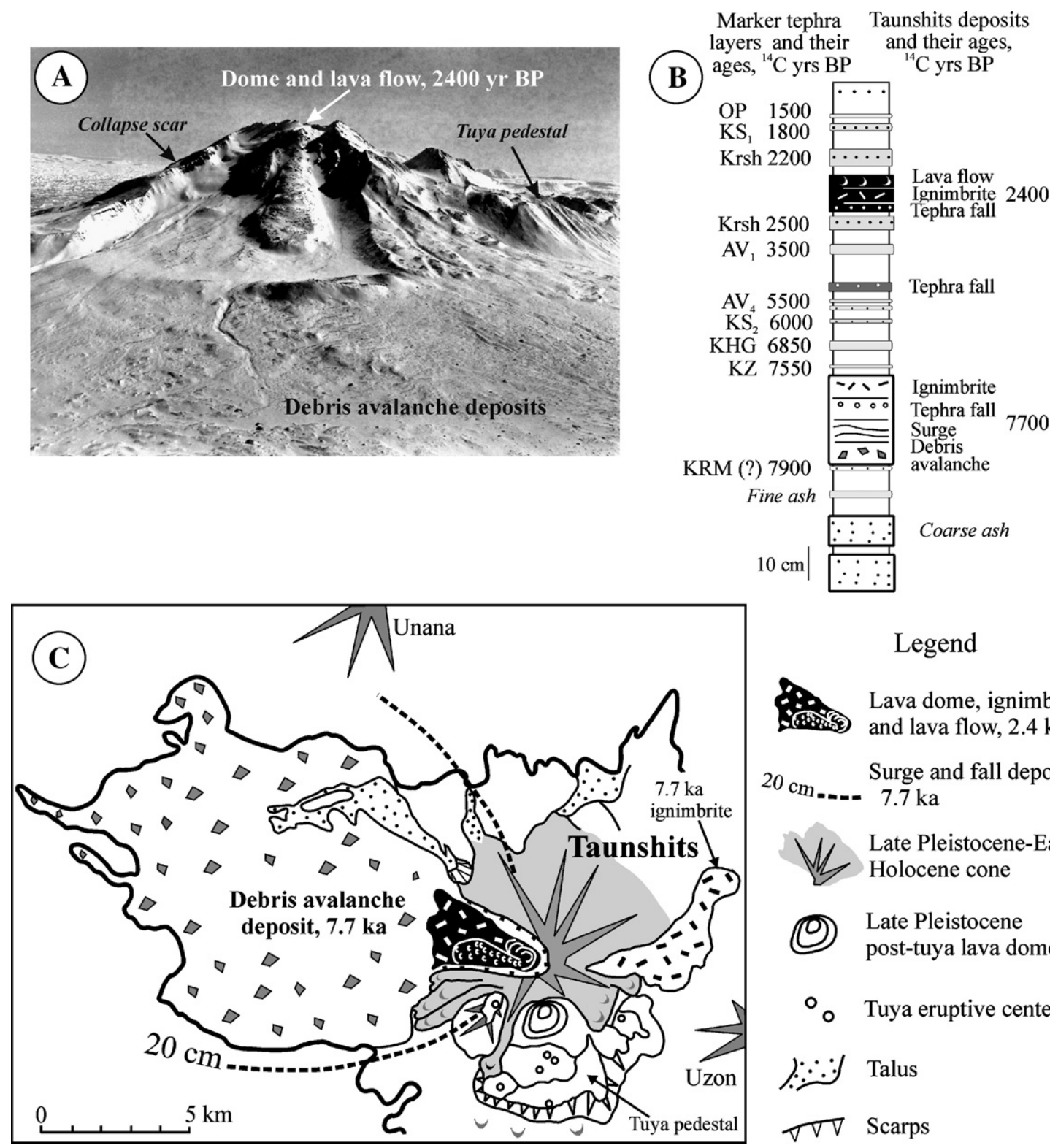

\section{Legend}

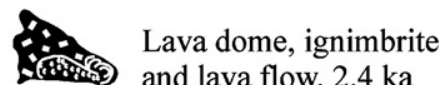

$20 \mathrm{~cm} \quad$ Surge and fall deposits, $7.7 \mathrm{ka}$

Late Pleistocene-Early

Holocene cone

(2) Late Pleistocene

post-tuya lava domes

○ Tuya eruptive centers

$\therefore$ Talus

$\checkmark \nabla$ Scarps

Fig. 9. Collapse related features on Taunshits volcano. A - General view of Taunshits from the west. Photo courtesy Nikolai Smelov. B Stratigraphic position of the Taunshits deposits with respect to marker tephra layers. Codes and ages of regional marker tephra layers as in Fig. 3. Local marker tephra layers (Krsh) are from Krasheninnikov volcano (Ponomareva, 1990). Vertical scale is for tephra layers. C — Schematic geological map of Taunshits volcano. Thick black line shows a boundary of the Taunshits rocks. For other symbols see Figs. 5 and 8.

et al., 1990). The main cone was built on the tuya pedestal in the latest Pleistocene to earliest Holocene. About $7700{ }^{14} \mathrm{C}$ yr BP a catastrophic eruption took place preceded by a failure of the western sector of the edifice. The landslide formed a large horseshoe-shaped crater $1.5 \mathrm{~km}$ in diameter that was the source of a debris avalanche with a volume of $3 \mathrm{~km}^{3}$ that traveled $\sim 19 \mathrm{~km}$ (Fig. 9A, C; Table 4). The debris-avalanche deposits are overlain by stratified pyroclastic surge, fall and pyroclastic current deposits (Fig. 9B). The most recent eruption of Taunshits took place about $2400{ }^{14} \mathrm{C}$ yr B.P. (Fig. 9B) and produced pyroclastic deposits and lava dome and flow partly filling the collapse crater (Fig. 9A).

Bakening volcano (2278 m a.s.l.; Figs. 1 and 10A) started to form in the latest Pleistocene and ceased its activity in the Early Holocene (Melekestsev et al., 1999). The position of the volcano at the edge of the 
Table 4

Debris avalanche deposits at the volcanoes of eastern and south Kamchatka

\begin{tabular}{|c|c|c|c|c|c|}
\hline Volcano & $\begin{array}{l}\text { Volume } \\
\left(\mathrm{km}^{3}\right)\end{array}$ & $\begin{array}{l}\text { Drop } \\
\text { height } \\
(H, \mathrm{~km})\end{array}$ & $\begin{array}{l}\text { Runout } \\
(L, \mathrm{~km})\end{array}$ & $\begin{array}{l}H / L \\
\text { ratio }\end{array}$ & $\begin{array}{l}\text { Age } \\
\left({ }^{14} \mathrm{C}, \text { yr BP }\right)\end{array}$ \\
\hline Komarov & 0.1 & 1 & 3 & 0.33 & 1000 \\
\hline Gamchen & 1 & 2 & 4 & 0.50 & $\begin{array}{l}\text { Early } \\
\text { Holocene }\end{array}$ \\
\hline Taunshits & 3 & 1.8 & 19 & 0.09 & 7700 \\
\hline Bakening & $0.4-0.5$ & 1.8 & 12 & 0.15 & $\begin{array}{l}\text { Late } \\
\text { Pleistocene }\end{array}$ \\
\hline Koriaksky & 0.1 & $>3$ & $>10$ & $<0.30$ & $\begin{array}{l}\text { Late } \\
\text { Pleistocene }\end{array}$ \\
\hline Avachinsky & $16-20$ & $>3$ & $\sim 30$ & $\sim 0.10$ & $\sim 30000$ \\
\hline Kozel'sky & $0.5-1$ & $>2$ & $>10$ & $\sim 0.20$ & $\begin{array}{l}\text { Late } \\
\text { Pleistocene }\end{array}$ \\
\hline Opala & $?$ & 2.3 & $?$ & $?$ & $\begin{array}{l}\text { Early } \\
\text { Holocene }\end{array}$ \\
\hline Mutnovsky & $>0.5$ & $\sim 2$ & $>10$ & $\sim 0.20$ & $1000-1500$ \\
\hline Khodutkinsky & $0.5-1$ & $>1.5$ & $>6$ & $<0.25$ & $\geq 2500$ \\
\hline Iliinsky & $\sim 10$ & 1.8 & $\sim 15$ & 0.12 & $\sim 7600$ \\
\hline Dikii Greben' & $2-2.5$ & 0.9 & 8 & 0.11 & 1600 \\
\hline Kambalny & $5-10$ & $\begin{array}{l}2.0 \\
2.2 \\
2.1\end{array}$ & $\begin{array}{l}14 \\
20 \\
10\end{array}$ & $\begin{array}{l}0.14 \\
0.11 \\
0.21\end{array}$ & $\sim 6300-6000$ \\
\hline
\end{tabular}

Avacha graben, over a system of bounding normal faults (Fig. 1), strongly affected the evolution of the cone both during and after its volcanic activity. There have been repetitive collapses of the SE sector of the volcano. The oldest one took place in the Late Pleistocene and created a large collapse crater. The debris avalanche from this event traveled as far as $12 \mathrm{~km}$ (Fig. 10B) and left a deposit of $0.4-0.5 \mathrm{~km}^{3}$ (Table 4). Afterwards, the volcano was active and produced lava flows which partly filled the collapse crater. In the Early Holocene (8500-8000 ${ }^{14} \mathrm{C}$ yr BP) a collapse of the SE sector occurred (Melekestev et al., 1999). Further destruction of the cone continued with at least five smaller landslides, producing a sequence of debris avalanche and smaller debris flow deposits along Srednyaya Avacha river and its tributaries (Fig. 10B, C). The volumes of Holocene deposits ranged from 0.001 to $0.007 \mathrm{~km}^{3}$. All the events created a $2.9 \times 1.35 \mathrm{~km}^{2}$ crater, which exposes an internal structure of the volcano (Fig. 10A). Only one of the landslides, the Early Holocene one, was associated with explosive activity (Fig. 10C). We suggest strong earthquakes as the main trigger for the rest of Bakening landslides because the Avacha graben is known for its modern shallow earthquakes (Gordeev et al., 2004) and paleoseismicity (Zobin et al., 1980).

Avachinsky volcano (2741 m a.s.l.; Figs. 1 and 11) is located a mere $20-30 \mathrm{~km}$ north of Petropavlovsk-
Kamchatsky's suburbs. Large collapses at 35-40 ka and 29-30 ka BP decapitated the Late Pleistocene edifice, covering an area of $\sim 300 \mathrm{~km}^{2}$ with hummocky debris avalanche deposits and leaving the huge intact Monastyr' toreva block at the foot of the volcano (Table 4; Melekestsev et al., 1992). The composition of Mt. Monastyr' rocks and their stratigraphy is similar to those of the Avachinsky Somma (M.Yu. Puzankov, pers.comm., 2004). The direction of the collapse was likely determined by asymmetry of the volcano and further subsidence of its southern foot. The avalanche was somewhat smaller than the Late Pleistocene Shiveluch one (Tables 1 and 4) and the resulting crater is rather narrow ( $\sim 5 \mathrm{~km}$ against $9 \mathrm{~km}$ for Shiveluch). No traces of eruptions closely following the sector collapses have been found (Melekestsev et al., 1992).

Koriaksky (3456 m a.s.1.) and Kozel'sky (2189 m) volcanoes adjacent to Avachinsky from northwest and southeast, respectively (Fig. 11B), have also experienced large landslides. On Koriaksky, there is a $\sim 0.1 \mathrm{~km}^{3}$ landslide crater on the SSE slope; the deposits are likely buried by younger lavas. The ENE slope of Kozel'sky was destroyed by a major collapse likely in Late Pleistocene (Fig. 11B) based on its relationship with glacial deposits and Holocene tephras.

\section{South Kamchatka}

Viliuchinsky volcano (2173 m a.s.l.; Fig. 1) ceased its activity in Early Holocene based on tephrochronological evidence. Now the volcano is being actively eroded principally by large, rain-triggered landslides. In 1981, during a heavy rainfall from Elsa typhoon, a 1$2 \times 10^{4} \mathrm{~m}^{3}$ piece of soil-pyroclastic cover slid down the western slope and triggered a lahar, which buried a car with two passengers in Paratunka River valley. On the western foot of the volcano a suite of earlier landslide-triggered lahar deposits include larger ones $\left(1 \times 10^{5}-10^{6} \mathrm{~m}^{3}\right)$ with an average recurrence interval of one per 500 and smaller events $\left(<1 \times 10^{4} \mathrm{~m}^{3}\right)$ one per 10 years.

Mutnovsky volcano (2322 m a.s.l.; Fig. 1) hosts a large hydrothermal field and a glacier in one of its craters; in addition, a large hydrothermal field of commercial value is located on its northern slopes (Fedotov and Masurenkov, 1991). Altered rocks of the Mutnovsky massif are prone to landslides and have produced a number of "wet" debris avalanches followed by lahars. One of the largest debris avalanches $\left(>0.5 \mathrm{~km}^{3}\right)$ descended for $10 \mathrm{~km}$; the deposits are characterized by a typical hummocky topography 


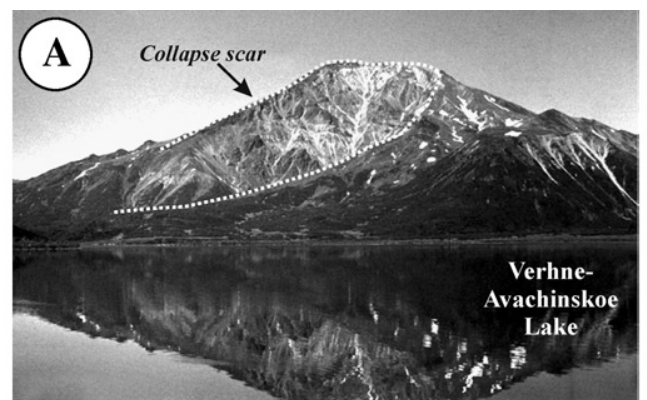

(C) Marker tephra layers, and their ages, ${ }^{14} \mathrm{C}$ yrs BP

\begin{tabular}{|c|c|c|}
\hline \multirow[b]{3}{*}{$\begin{array}{r}\text { Kostakan cinder } 600-1200 \\
\text { OP } 1500\end{array}$} & & deposits and ${ }^{14} \mathrm{C}$ dates \\
\hline & $\rightarrow \Delta$ & \multirow{4}{*}{$\begin{array}{l}\text { Series of debris } \\
\text { avalanche/ debris } \\
\text { flow deposits }\end{array}$} \\
\hline & $\ldots$ & \\
\hline $\mathrm{KS}_{1} 1800$ & $\cdots$ & \\
\hline \multirow[t]{3}{*}{ Zavaritsky cinder 2800} & $\because \therefore \therefore$ & \\
\hline & $\rightarrow$ & Series of debris \\
\hline & $\rightarrow$ & $\begin{array}{l}\text { avalanche/ debris } \\
\text { flow deposits }\end{array}$ \\
\hline \multirow{4}{*}{$\begin{array}{rr}\text { KHG } & 6850 \\
\text { KO } & 7600\end{array}$} & & $7810 \pm 40$ \\
\hline & & $7690 \pm 50$ \\
\hline & $\therefore$ & Ignimbrite \\
\hline & 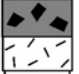 & $\begin{array}{l}\text { Debris avalanche deposit } \\
\text { Ignimbrite }\end{array}$ \\
\hline Holocene & 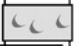 & Lava flows \\
\hline Late Pleistocene & $\Delta \nabla \Delta$ & $\begin{array}{l}\text { Major debris } \\
\text { avalanche deposit }\end{array}$ \\
\hline
\end{tabular}

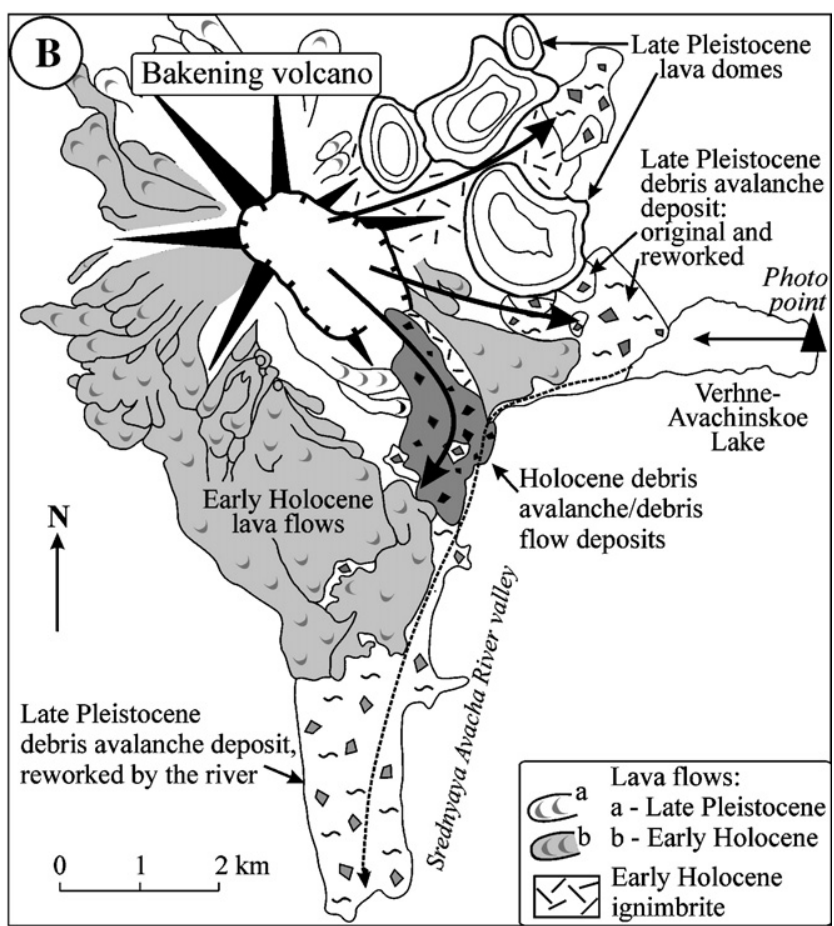

Fig. 10. Collapse related features on Bakening volcano. A - Collapse amphitheater seen from the east. Photo courtesy Alexey Tsyurupa. B Schematic geological map of Bakening volcano. For symbols see Figs. 5 and 8. Thick arrows show the direction of mass movement. C Stratigraphic position of Bakening debris avalanche and landslide deposits. Ages and codes of regional marker tephra layers as in Fig. 3. Local marker cinder layers are from Kostakan and Zavaritsky cinder cones (Braitseva and Pevzner, 2001).

and contain large $(5-15 \mathrm{~m})$ blocks in a matrix of altered rocks. This avalanche occurred between 1000 and $1500 \mathrm{yr}$ BP, based on relationship of its deposits with marker tephra layers, and was accompanied by a phreatic eruption (Melekestsev and Braitseva, 1984).

Opala (2460 m a.s.1.) and Khodutka (2089 m) volcanoes (Fig. 1) both have evidence of past collapse events, not yet studied in detail. Opala volcano is located on the northern rim of a Late Pleistocene caldera and rises $\sim 2400 \mathrm{~m}$ above the caldera bottom. An Early Holocene debris-avalanche deposit is present at the bottom of the caldera, $8 \mathrm{~km}$ south of the volcano's summit. A smaller landslide on the southern slope of the volcano preceded an eruption of silicic lava and pumiceous tephra $\sim 3500{ }^{14} \mathrm{C}$ yr BP as suggested by tephrochronological data. On Khodutka, a landslide crater and related deposits are present on the northeast- ern slope. The landslide is somewhat younger than 2500 ${ }^{14} \mathrm{C}$ yr BP since no KHD marker tephra from Khodutkinsky crater was found on its surface.

Dikii Greben' Holocene extrusive massif (1079 m a.s.1., Fig. 12) includes landslide deposits unique in Kamchatka. Our field studies have been reconnaissance in character, but we provide new data to attract attention to this volcano. This dominantly rhyodacitic (Bindeman and Bailey, 1994) eruptive center is located immediately west of the Kurile Lake caldera and consists of a main lava dome Mt. Nepriyatnaya and a number of flank domes, occupying with their lava and pyroclastic flows an area of more than $60 \mathrm{~km}^{2}$ (Fig. 12A,B). Dikii Greben' was apparently formed during three short stages of activity separated by $\sim 3000$-yr long repose periods. It started to form immediately after the Kurile Lake caldera collapse about $7600{ }^{14} \mathrm{C}$ yr BP, and then was active 

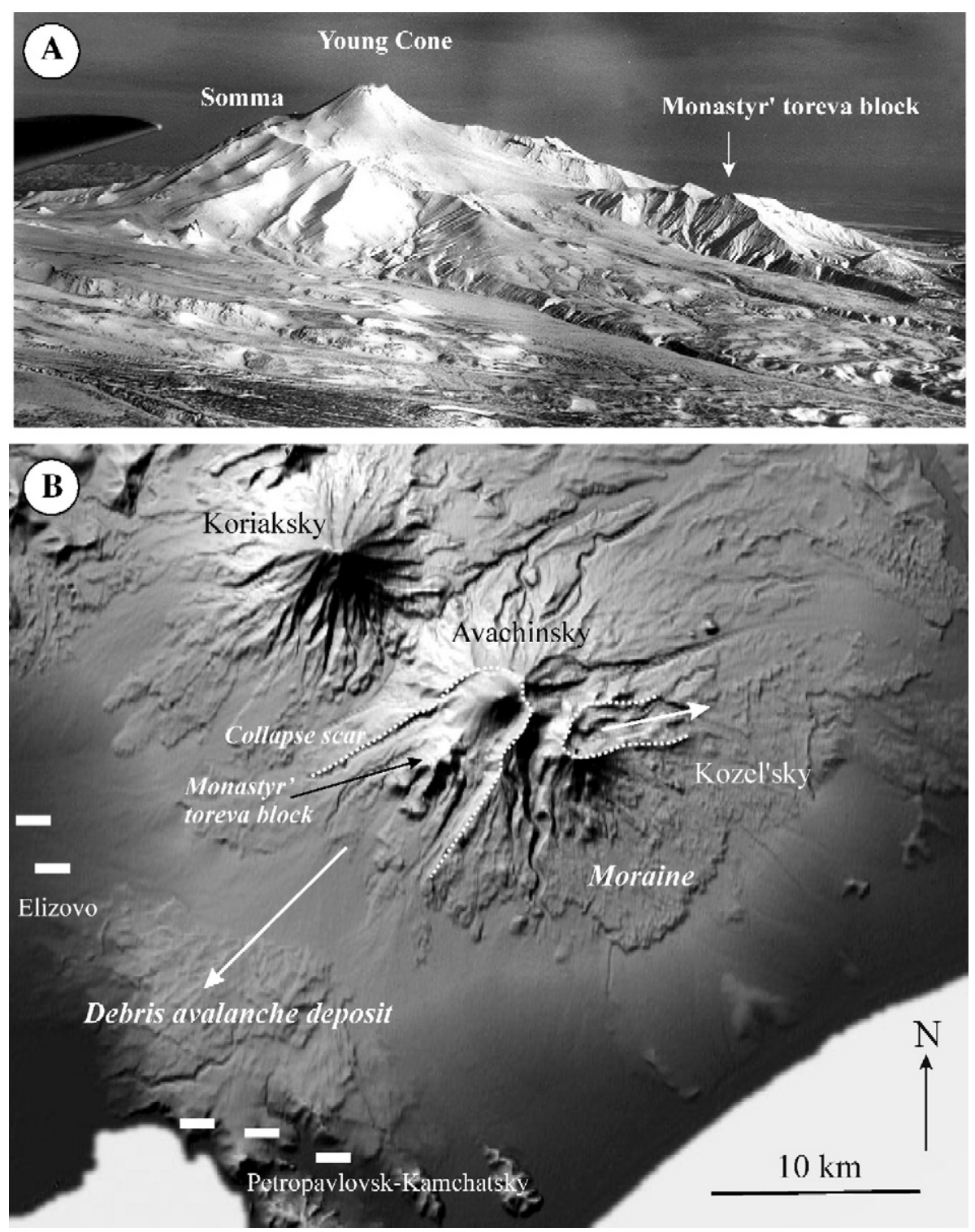

Fig. 11. A - Avachinsky volcano viewed from the west. Large Pleistocene Somma encloses the active Young Cone. The volcano was destroyed by at least two sector collapses 40-30 ka BP; Mt. Monastyr' is a $\sim 2 \mathrm{~km}^{3}$ toreva block displaced during one of these events. Photo courtesy Nikolai Smelov. B - Shaded SRTM elevation model showing the crater and debris avalanche deposits of the Late Pleistocene sector collapses from Avachinsky volcano and a scar of the Late Pleistocene collapse on Kozel'sky volcano. Cities of Elizovo and Petropavlovsk-Kamchatsky are schematically shown with white rectangles. A part of the image released by NASA/JPL/NIMA.

around $4300{ }^{14} \mathrm{C}$ yr BP and $\sim 1600{ }^{14} \mathrm{C}$ yr BP, when the largest part of the present edifice formed (Ponomareva et al., 1995).

The most recent eruption produced a tephra-fall deposit, several lava domes and a $>350 \mathrm{~m}$ thick, $4 \mathrm{~km}$ long southern lava flow with well-expressed marginal levées and arcuate pressure ridges, fairly typical example of a coulée (Guest and Sánchez, 1969; Fink, 1980). In addition, east and north of the main dome, two large lava bodies were formed, whose features are better explained as originating from sector collapse of the dome(s). The eastern body consists mostly of huge dome chunks forming specific steps towards the Kurile Lake and stopped by an older dome (Fig. 12A, B). The northern lava body is $\sim 8 \mathrm{~km}$ long and $>200 \mathrm{~m}$ thick with a volume of $4-5 \mathrm{~km}^{3}$. It resembles viscous blocky lava flow with marginal levées and $\sim 50 \mathrm{~m}$ high ogive-like ridges, but unlike those in a regular lava flow, these are arcuate against the direction of motion (Fig. 12A, B). The most distal 

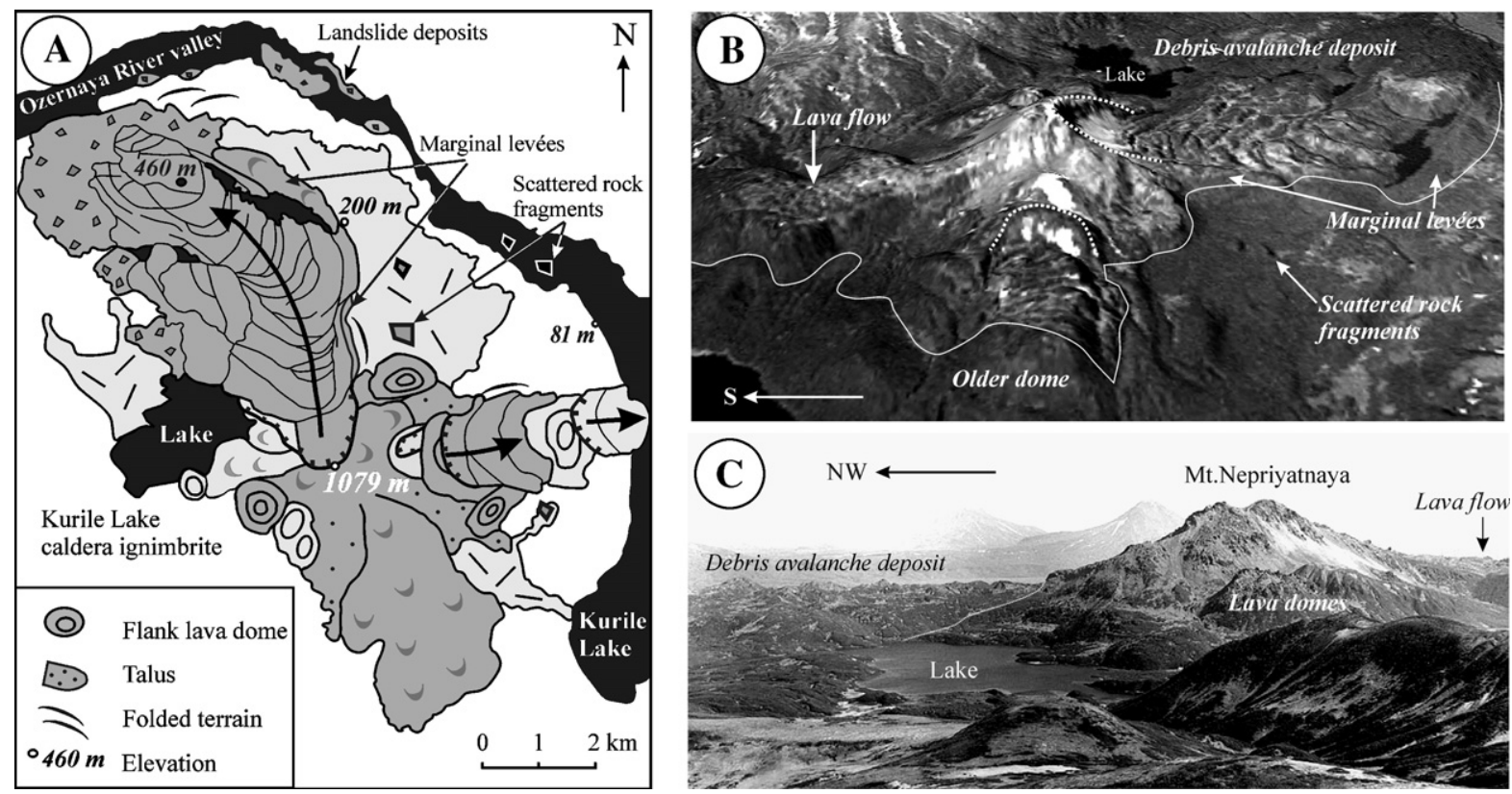

Fig. 12. Collapse related features at Dikii Greben' volcano. A - Schematic geological map. Deposits of the most recent eruption from Dikii Greben' (1600 yr BP) are shown with darker shading; earlier deposits of the volcano - with lighter one; Kurile Lake caldera ignimbrite, underlying the Dikii Greben' deposits, is not shaded. Lakes and Ozernaya River valley are black. Solid lines on the northern and eastern rock avalanche deposits show large portions of the displaced rocks. Thick arrows show the direction of mass motion. Scattered rock fragments around the volcano are not to scale (see the text for explanation). For other symbols see Figs. 5 and 8. B - Landsat 7 image of Dikii Greben' volcano draped over a digital elevation model. Processed by Dmitry Melnikov. Solid white line bounds the 1600 yr BP deposits from the east. Dotted white lines show collapse scars. C Dikii Greben' volcano seen from the southwest. Photo courtesy Nikolai Smelov.

part of the deposit exhibits hummocky topography typical of a debris avalanche. The presumed collapse scar on the northern side of the main dome is a 700m-high steep slope with talus at the foot. Folds of the underlying deposits, resembling those described for Jocotitlan volcano by Siebe et al. (1992) or for Shiveluch by Ponomareva et al. (1998) and Belousov et al. (1999), are observed along the margins of both lava bodies (Fig. 12A).

Quite a few blocks of Dikii Greben' rhyodacite from 40 to $2-5 \mathrm{~m}$ across and numerous smaller debris are scattered northeast of the main dome; the most distal are $\sim 2 \mathrm{~km}$ away from the nearest parent material (Fig. 12A). All observed blocks are dissected by cracks likely resulting from hard landing. The only way to explain the transportation of these blocks is to suggest that they became detached from the main avalanche and bounced and rolled down the slope.

These observations suggest a collapse origin for both northern and eastern lava bodies. However, some of the northern body's features can hardly be explained by this only mechanism. Well-preserved marginal levées, bounding the deposit from NE (Fig. 12A), evidence the existence of a lava flow earlier in this eruption, most of which was then overriden by a debris avalanche Most of the avalanche deposit consists of large lava chunks without any sandy matrix. The degree of fragmentation grows with the travel distance and is highest at its distal part (Fig. 12A). Volume of the debris avalanche deposit likely constituted about a half of the 4-5 $\mathrm{km}^{3}$ total for the northern lava body (Table 4).

Slope failures involving active hot domes can trigger large explosive eruptions (e.g. Voight et al., 1981; Newhall and Melson, 1983; Alidibirov and Dingwell, 1996; Voight, 2000). In this case, collapse deposits are overlain by only moderate tephra fall deposit, suggesting the domes were not pressurized enough to produce a large eruption. So we speculate that both north and east sector collapses took place somewhat later than the main dome-building stage.

Kambalny (2161 m a.s.l.) is the southernmost active volcano of the Kamchatka arc. This Holocene mafic stratovolcano sits on the southern tip of older hydrothermally altered volcanic ridge, on the rim of a $5 \times 3.5$ km-wide collapse crater (Figs. 13 and 14). The Holocene edifice is strongly asymmetrical (Fig. 14D). Kambalny probably emerged in Early Holocene since lava flows at its older western slope are not overlain by 

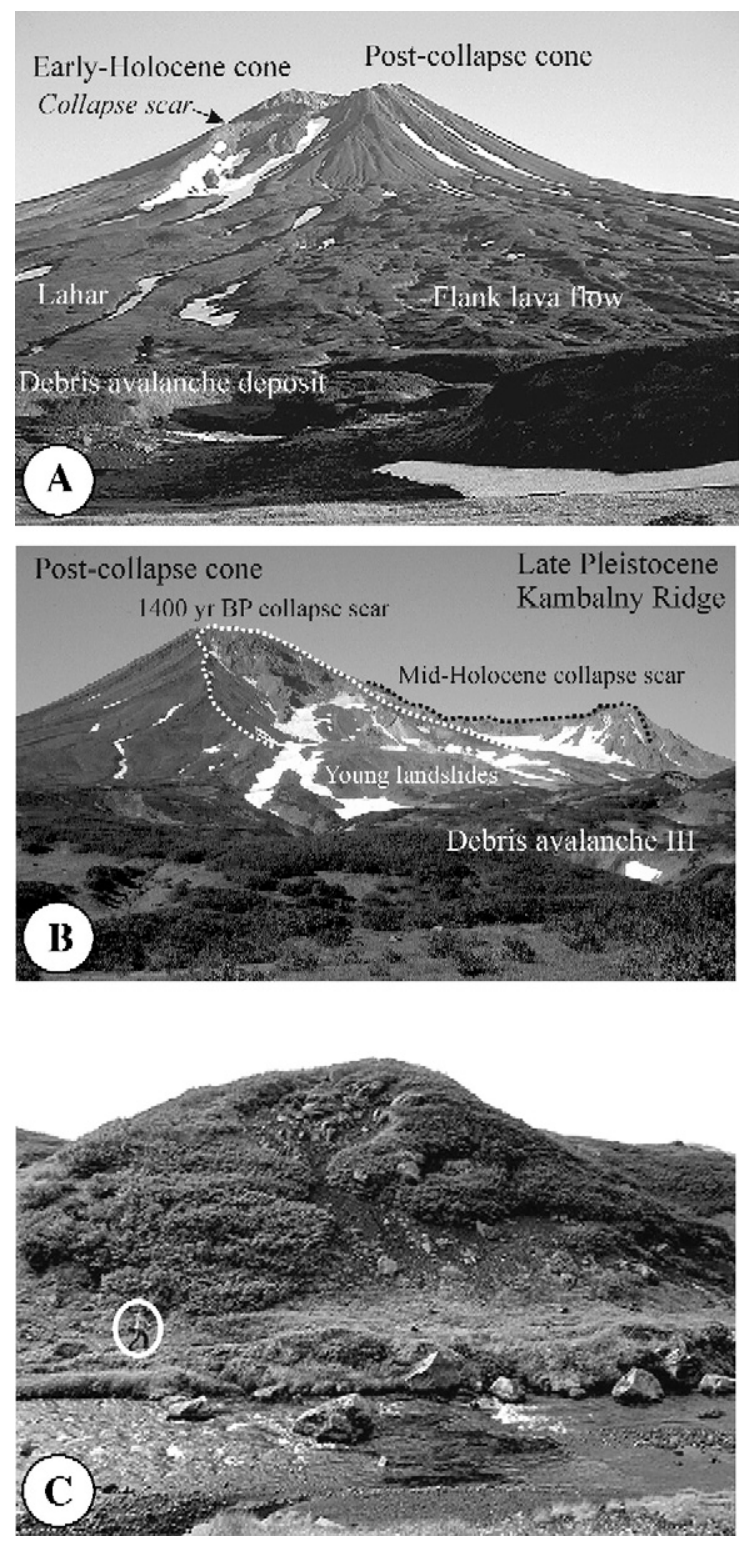

Fig. 13. Collapse related features on Kambalny volcano, south Kamchatka. A - Southern slope of the volcano. B - Northeastern slope of the volcano. C - A hummock of debris avalanche II south of the volcano, note a person in white circle for scale. Debris avalanche II deposit is composed by large fragments of basaltic lava in a matrix of splintered red and black scoria. Photos courtesy L.D. Sulerzhitsky.

any glacial deposits but bear a thick soil-pyroclastic sequence. About $6300{ }^{14} \mathrm{C}$ yr BP the volcano was destroyed by voluminous sector collapses, which formed at least three debris-avalanche units (Fig. 14A, C). The older two debris-avalanche units are composed of mafic lava blocks and splintered scoria, they were earlier mapped as lava flows (Fedotov and Masurenkov,
1991), but both units have a typical hummocky topography and consist of debris from bottom to top. The first avalanche traveled $14 \mathrm{~km}$ southeastwards. Then a series of strong explosive eruptions started to build a new cone east of the Early Holocene one and covered the first avalanche unit with thick stratified cinders. The next collapse involved both old and emerging cones and resulted in the second debris avalanche, which surmounted 350-m-high hills and formed a 5-km-wide and 20-km-long deposit SSW from the volcano (Figs. 13C and 14A and D). The third debris avalanche originated from the large landslide amphitheater carved into the Late Pleistocene ridge but also involved some rocks of the Holocene cone. The resulting deposit is dominated by strongly altered clayey rocks of the older ridge. This third avalanche went more than $10 \mathrm{~km}$ down the Khakytsyn River valley, and in its most distal part consists of three sub-units. These are from bottom to top: 1) a clast supported zone with a minor amount of matrix, 2) a zone enriched in fine material predominantly of clay size, and 3) a zone enriched in pumice clasts (picked up from older Kurile Lake caldera ignimbrite) with a fine matrix. Such a sequence is believed to have formed as a result of high water concentration in the avalanche sufficient for sinking of dense clasts and the rise of buoyant pumice (as in Palmer et al., 1991). This third avalanche is characterized by a hummocky topography which is in part smoothed by a subsequent mafic pyroclastic density current and in places covered by landslides from the walls of the Khakytsyn River valley composed of the Kurile Lake caldera ignimbrite.

The total volume of all the three units is roughly estimated at $5-10 \mathrm{~km}^{3}$, the largest Holocene collapse in Kamchatka. Subsequent eruptions have built a new cone and almost completely masked a collapse crater on the Kambalny edifice (Fig. 13A) but not on the Late Pleistocene ridge (Fig. 13B).

Now this large amphitheater encloses long-living snowpacks and a glacier. The inner south and southwestern walls of the amphitheater expose a large field of hydrothermally altered rocks. Repetitive sliding of these altered rocks during the Late Holocene has resulted in water-saturated landslides down the Khakytsyn River. The stratigraphic relationships of these landslide deposits with Kambalny tephra layers suggest that they were associated with its activity (Fig. 14C). Some of these landslides triggered lahars. Resumption of volcanic activity might cause new wet debris avalanches and lahars in the Khakytsyn valley and might also affect Kurile Lake. The general causes of Kambalny collapses are its strong asymmetry, presence 

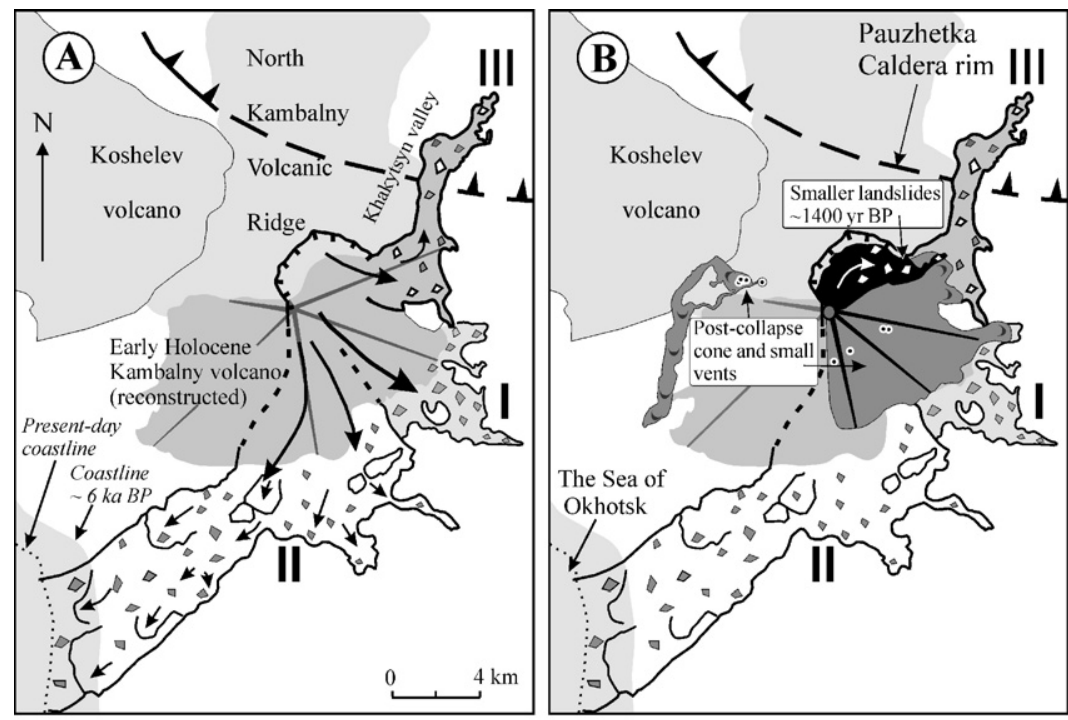

(C)

(D)

Schematic profile along the North Kambalny Ridge

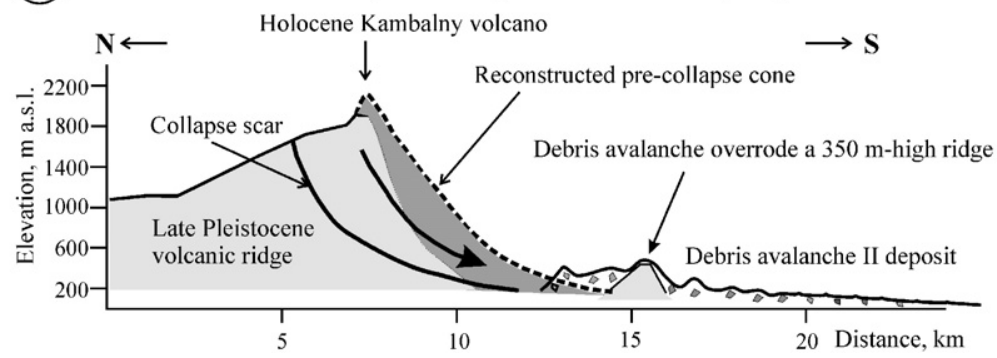

Marker tephra
layers and their
ages, ${ }^{14} \mathrm{C}$ yrs BP
KSht $_{1} 1100$

DG III 1600

KHD 25

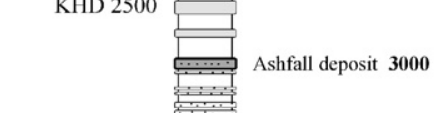

$3700-4000$ Iliinsky cinders

DG II 4300

\section{0}

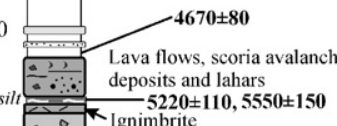

Kambalny

deposits

and their ages,

${ }^{14} \mathrm{C}$ yrs BP

Phreatic ash $\sim 500$

Lava flow,

scoria avalanche deposit andslides and lahars 1400

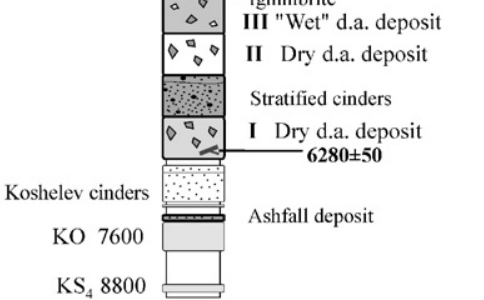

Fig. 14. Collapse related features on Kambalny volcano. A - Schematic map of local geology and deposits of three successive debris avalanches (6.3-6 ka BP). For symbols see Figs. 5 and 8. B - Post-collapse cone and flank vents, and subsequent landslides from the walls of the collapse crater. $\mathrm{C}$ - Stratigraphic position of the Kambalny debris avalanche and landslide deposits. Codes and ages of regional marker tephra layers as in Fig. 3; local tephras according to Ponomareva et al. (2001). DG II and DG III — tephras from Dikii Greben' volcano. d.a. $=$ debris avalanche. D — Schematic profile along the North Kambalny Ridge.

of strongly altered and water-saturated rocks under the volcano and, likely, strong regional seismicity.

\section{Collapses associated with calderas}

Kamchatka hosts eight Holocene and at least 40 older large collapse calderas associated with both explosive and effusive eruptions (Leonov, 2003). Caldera collapse was suggested to be an effective trigger of large landslides in volcanic terrains, specifically on steep and hydrothermally altered volcanoes (Hürlimann et al., 2000). Kamchatka examples demonstrate that landslides from caldera walls including those from volcanic edifices cut by ring-faults are ubiquitous (Melekestsev and Braitseva, 1984). Some of the landslides from volcanoes cut by caldera faults likely occurred during caldera formation, as is suggested by common sense, stability analysis (Hürlimann et al., 2000) and sand-box modelling (Belousov et al., 2005). Later landslides worked as the main agents changing caldera shape and size and likely were triggered by earthquakes or heavy rainfalls. Large Holocene landslides have been driven, in particular, from the inner walls of Uzon volcano and Mt. Dvugorbaya, cut by the rims of the Late Pleistocene Uzon and Gorelaya calderas, respectively (Melekestsev and Braitseva, 1984). Both landslides happened more than $30 \mathrm{ka}$ after caldera collapse.

Some large collapses of edifices close to caldera rims likely happened prior to caldera formation, perhaps due to earthquakes preceding caldera-forming eruptions. One of these cases is that of Dvor volcano at the flank of Karymsky caldera (Ivanov, 1970), based on the present shape of its collapse amphitheater, which is different from those formed simultaneously with caldera subsidence (Belousov et al., 2005). Another Kamchatka example is the pre-Iliinsky 
Somma-volcano, which encloses modern Iliinsky and sits immediately northeast of the 7.6 ka Kurile Lake caldera. Blocks from pre-Iliinsky lie in the depression predating the caldera and are overlain by ignimbrite associated with the caldera-forming eruption (Bondarenko, 1991), so we speculate that earthquakes accompanying magma ascent prior to the eruption might have caused sector collapse of the pre-Iliinsky edifice (Ponomareva et al., 2004).

\section{Discussion}

Our overview of landslides on Kamchatka volcanoes shows that they have been common and have acted as one of the main geomorphic agents on the volcanic edifices. Landslides are favored by the high volcanic productivity and fast growth of Kamchatka volcanoes; by significant height $(2-4 \mathrm{~km})$ of volcanic edifices above their surroundings; by typically steep slopes (30$40^{\circ}$ for stratovolcanoes and cinder cones, $30-60^{\circ}$ for extrusive domes, $45-90^{\circ}$ for crater and caldera rims); and by networks of fractures and dykes (as in Elsworth and Voight, 1996; Tibaldi, 1996). Additional factors include heterogeneity of geological structure such as loose or plastic clayey rocks formed due to hydrothermal activity, interbedded lavas and pyroclastics, different in their physical characteristics, and the presence of cryptodomes, sills, summit domes and lava plugs. Causes, mechanisms, recurrence rates and volumes of landslides vary depending on morphology of the volcanic edifice, its productivity, type and intensity of eruptions, magma composition and viscosity, and characteristics of the basement. Triggers for volcanic landslides include magma intrusions prior to and in the course of the eruptions, which cause deformation of volcanic edifices and local earthquakes; strong regional crustal and subduction-related earthquakes; local earthquakes associated with eruption of neighbouring volcanoes; and over-saturation of the volcanic rocks with water due to heavy rain-falls or permafrost, snow and ice melting. The largest collapses in Kamchatka produced debris avalanches with volumes of resulting deposits up to $30 \mathrm{~km}^{3}$ and toreva blocks up to $2 \mathrm{~km}^{3}$. The maximum vertical amplitude of the debris material displacement exceeded $4 \mathrm{~km}$ (on Kamen' volcano) and the horizontal amplitude $30 \mathrm{~km}$ (on Shiveluch, Kamen' and Avachinsky).

Seven active volcanoes in Kamchatka exhibit a classic Somma-Vesuvius structure with an older destroyed edifice embracing a young active center. These are Shiveluch (Fig. 4), Zarechny (Fig. 2B), Bezymianny (Fig. 2A), Taunshits (Fig. 9A), Avachinsky
(Fig. 11), Iliinsky, and Kambalny (Fig. 13A). Some Sommas are composed of a suite of rocks from basaltic andesites to andesites (Old Shiveluch, pre-Bezymianny, Taunshits, Avachinsky Somma and, probably, preIliinsky), while Zarechny and Kambalny are uniformly mafic. Young eruptive centers may consist of one or more silicic extrusive domes (Young Shiveluch, Bezymianny, Taunshits), may be represented by a mafic stratovolcano (Kambalny) or by composite edifices including silicic domes buried by mafic cones (Young Cone of Avachinsky and Iliinsky) or a mafic cone with later andesitic domes (Zarechny).

The largest sector collapses identified so far on Kamchatka volcanoes, with volumes of resulting debris avalanche deposits of $20-30 \mathrm{~km}^{3}$, occurred at Shiveluch and Avachinsky volcanoes in the Late Pleistocene time. Both collapses took place most likely during the last glacial interstadial (30-40 ka BP) roughly at the same period as many Late Pleistocene collapse calderas (Braitseva et al., 1995). Both sector collapses likely were not followed by large explosive eruptions, so they were probably caused by factors other than magmatic activity.

During the last 10,000 yr the most voluminous sector collapses happened at extinct Kamen' $\left(4-6 \mathrm{~km}^{3}\right)$ and active Kambalny $\left(5-10 \mathrm{~km}^{3}\right)$ volcanoes. The largest number of repetitive debris avalanches $(>10$ only during just the second half of Holocene) occurred at Shiveluch volcano. On the active volcanoes with well-documented deposits, most if not all of the collapses were associated with volcanic activity. Eruptions preceding sector collapses produced both silicic (Dikii Greben') or mafic (Plosky Dalny) lava or, in one case, basaltic andesitic cinder (Kambalny eruption prior to avalanches II and III). Collapse-triggered eruptions produced only tephra: both silicic (e.g. Shiveluch, Bezymianny, Taunshits) and mafic (Kambalny). The largest partial collapses of active or nearly active domes ranged from $0.05 \mathrm{~km}^{3}$ (2004 Shiveluch and 1985 Bezymianny collapses) to $2-2.5 \mathrm{~km}^{3}$ on Dikii Greben' ( $1600 \mathrm{yr}$ BP). Most of the Kamchatka avalanches were relatively dry and not rich in fragments of strongly altered rocks or clay. We count only three "wet" debris avalanches, namely from Komarov, Mutnovsky and Kambalny (avalanche III) volcanoes.

Collapses on the volcanoes which have stopped their activity might have been triggered by earthquakes associated with eruptions of neighbouring volcanoes. This case is documented for the most recent $(\sim 1200 \mathrm{yr}$ BP) flank failures of extinct Kamen' and Ovalnaya Zimina volcanoes (Braitseva et al., 1991), and this was probably also the case of extinct Plosky Blizhny volcano 
collapse (associated with the collapse of summit caldera on Plosky Dalny) and of extinct Ostry Tolbachik (associated with the collapse of summit caldera on Plosky Tolbachik).

Large collapses have occurred around Kamchatka, but the highest concentration is within the Central Kamchatka Depression with its most voluminous volcanoes (Figs. 1 and 3). This concentration suggests that the main reason for sector collapse lies in high magma production rate, which results in frequent large eruptions and fast growth of volcanic edifices. This conclusion is supported by analyses of time distribution of dated Holocene collapses (Fig. 3), of which 13 occurred on 8 volcanoes between 1100 and $1900 \mathrm{yr}$ BP, coinciding with a period of enhanced volcanic activity on Kamchatka (Braitseva et al., 1995). Any other time interval of similar duration gives no more than 5 collapse events on 3 volcanoes.

Most of the volcanoes which have experienced sector collapses are located outside identified regional active fault systems (Fig. 1). Orientation of collapse craters does not support their relation to these systems and rather seems controlled by local faults. Only three collapsed volcanoes, Bakening, Komarov and Gamchen, which are associated with dip-slip faults (Kozhurin, 2004), might have depended on fault activity (as in Lagmay et al., 2000; Vidal and Merle, 2000); their collapse scars are oriented accordingly (Figs. 1, 8 and 10)).

Volcanoes likely to experience large sector collapses in the future are Kliuchevskoi, Kizimen (Melekestsev et al., 1995), Young Cone of Avachinsky, Opala, Iliinsky and Kambalny (Fig. 1). This prediction is supported by their strong asymmetry, history of previous collapses (for the four latter volcanoes), and fast growth. Collapse of Koriaksky volcano has been also predicted based on its morphology and long repose period, which may have favored accumulation of a large amount of magma under the volcano (Melekestsev et al., 1992).

About $80 \%$ of $\sim 350,000$ people inhabiting Kamchatka concentrate in three cities: PetropavlovskKamchatsky and Elizovo, located $\sim 30 \mathrm{~km}$ south of Koriaksky and Avachinsky volcanoes (Fig. 11), and Kliuchi, located $30 \mathrm{~km}$ north of Kliuchevskoi and $45 \mathrm{~km}$ south of Shiveluch volcanoes (Fig. 1). For the historical period ( $\sim 300$ years), these sites have experienced volcanic influence only by minor ashfalls and minor flooding in outermost suburbs. Collapses of high, steep volcanoes can produce very mobile and hazardous debris avalanches (Siebert, 1984, 1996), which may bury an area under thick cover of debris and may change river drainages (as in Waythomas, 2001). Prediction of collapses on Kliuchevskoi, Avachinsky and Koriaksky highlights the importance of closer studies of their structure and stability. Moreover an avalanche from Iliinsky volcano could produce a tsunami in Kurile Lake and down Ozernaya River, which flows from the lake toward several villages. Kizimen, Opala and Kambalny are located far from the populated areas but their collapses still may be dangerous for tourists, fishermen and hunters who visit their surroundings.

\section{Acknowledgements}

The research described in this paper was supported in part by the Russian Foundation for Basic Research (grants \#\#06-05-64960 and 06-05-65037) and by the Russian Academy of Sciences Program "Environmental and Climate Change". Field work was funded in part by grants \#\# 5926-97 and 6831-00 from the National Geographic Society. Financial support from NSF grant \#EAR-0125787 to Joanne Bourgeois has allowed Vera Ponomareva to accomplish her work on the manuscript. The authors are grateful to Lee Siebert, Chris Waythomas and Federico Pasquaré, who made valuable comments and suggestions, greatly improving the paper. Joanne Bourgeois's help in editing the manuscript is highly appreciated. This work has been done in the framework of UNESCO-IUGS-IGCP project n. 455 and ILP project "New tectonic causes of volcano failure and possible premonitory signals".

\section{References}

Alidibirov, M., Dingwell, D., 1996. Magma fragmentation by rapid decompression. Nature 380, 146-148.

Bazanova, L.I., Pevzner, M.M., 2001. Khangar: one more active volcano in Kamchatka. Trans. Russ. Acad. Sci. Earth Sci. 377A, 307-310.

Belousov, A.B., 1995. The Shiveluch volcanic eruption of 12 November 1964 - explosive eruption provoked by failure of the edifice. J. Volcanol. Geotherm. Res. 66, 357-365.

Belousov, A.B., 1996. Pyroclastic deposits of March 30, 1956 directed blast at Bezymianny volcano. Bull. Volcanol. 57, 649-662.

Belousov, A.B., Belousova, M.G., 1998. Bezymiannyi eruption on March 30, 1956 (Kamchatka): sequence of events and debrisavalanche deposits. Volcanol. Seismol. 20, 29-49.

Belousov, A., Belousova, M., Voight, B., 1999. Multiple edifice failures, debris avalanches and associated eruptions in the Holocene history of Shiveluch volcano, Kamchatka, Russia. Bull. Volcanol. 61, 324-342.

Belousov, A., Walter, T.R., Troll, V.R., 2005. Large-scale failures on domes and stratocones situated on caldera ring faults: sand-box modeling of natural examples from Kamchatka, Russia. Bull. Volcanol. 67 (5), 457-468.

Bindeman, I.N., Bailey, J.C., 1994. A model of reverse differentiation at Dikii Greben' volcano, Kamchatka: progressive basic magma 
vesiculation in a silicic magma chamber. Contrib. Mineral. Petrol. $117,263-278$.

Bogoyavlenskaya, G.E., Braitseva, O.A., Melekestsev, I.V., Kiriyanov, V.Yu., Miller, C.D., 1985. Catastrophic eruptions of the directedblast type of Mount St. Helens, Bezymianny and Shiveluch volcanoes. J. Geodyn. 3, 189-218.

Bondarenko, V.I., 1991. Seismic reflection profiling in Lake Kurilskoe. Volcanol. Seismol. 12 (4), 533-548.

Braitseva, O.A., Pevzner, M.M., 2001. Novo-Bakening volcano of Kamchatka: its age and tephra stratigraphy. Volcanol. Seismol. 22, 581-594.

Braitseva, O.A., Melekestsev, I.V., Bogoyavlenskaya, G.E., Maksimov, A.P., 1991. Bezymianny volcano: the history of formation and activity dynamics. Volcanol. Seismol. 12, 165-194.

Braitseva, O.A., Melekestsev, I.V., Ponomareva, V.V., Sulerzhitsky, L.D., 1995. The ages of calderas, large explosive craters and active volcanoes in the Kuril-Kamchatka region, Russia. Bull. Volcanol. 57 (6), 383-402.

Braitseva, O.A., Sulerzhitsky, L.D., Ponomareva, V.V., Melekestsev, I.V., 1997a. Geochronology of the greatest Holocene explosive eruptions in Kamchatka and their imprint on the Greenland glacier shield. Trans. Russ. Acad. Sci. 352 (1), 138-140.

Braitseva, O.A., Ponomareva, V.V., Sulerzhitsky, L.D., Melekestsev, I.V., Bailey, J., 1997b. Holocene key-marker tephra layers in Kamchatka, Russia. Quat. Res. 47 (2), 125-139.

Churikova, T., Dorendorf, F., Woerner, G., 2001. Sources and fluids in the mantle wedge below Kamchatka, evidence from across-arc geochemical variation. J. Petrol. 42 (8), 1567-1593.

Dvigalo, V.N., 1984. Growth of the dome in the crater of Shiveluch volcano in 1980-1981 according to photogrammetric data. Volcanol. Seismol. 2, 104-109 (in Russian).

Dvigalo, V.N., Melekestsev, I.V., 2000. Recent large-scale downfalls on the cone of Klychevskoy volcano: a revision of the consequences of the events of 1944-1945, 1984-1985 and 1999. Volcanol. Seismol. 22, 1-23.

Elsworth, D., Voight, B., 1996. Evaluation of volcano flank instability triggered by dyke intrusion. In: McGuire, W.J., Jones, A.P., Neuberg, J. (Eds.), Volcano Instability on the Earth and Other Planets. Geol. Soc. Special Publ., vol. 110, pp. 45-53.

Fedotov, S.A., Masurenkov, Yu.P. (Eds.), 1991. Active Volcanoes of Kamchatka. Nauka, Moscow.

Fedotov, S.A., Dvigalo, V.N., Zharinov, N.A., Ivanov, V.V., Seliverstov, N.I., Khubunaya, S.A., Demyanchuk, Yu.V., Markov, I.A., Osipenko, L.G., Smelov, N.P., 2001. Eruption of Shiveluch volcano in May-July 2001. Volcanol. Seismol. 6, 3-15 (in Russian).

Fink, J., 1980. Surface folding and viscosity of rhyolite flows. Geology 8 (5), 250-254

Firstov, P.P., Gavrilov, V.A., Zhdanova, E.Yu., Kiriyanov, V.Yu., 1995. New extrusive eruption of Shiveluch in April 1993. Volcanol. Seismol. 16, 371-386.

Francis, P.W., Gardeweg, M., Ramirez, C.P., Rothery, D.A., 1985. Catastrophic debris avalanche deposit of Socompa volcano, northern Chile. Geology 13, 600-603.

Glicken, H., 1986. Rockslide-debris avalanche of May 18, 1980, Mount St. Helens volcano, Washington. The University of California. Santa Barbara, Ph. D. Dissertation. 303 pp.

Gorbatov, A., Kostoglodov, V., Suarez, G., Gordeev, E.I., 1997. Seismicity and structure of the Kamchatka subduction zone. J. Geophys. Res., B 102 (8), 17,883-17,898.

Gordeev, E.I., Gusev, A.A., Levina, V.I., Leonov, V.L., Chebrov, V.A., 2004. Crustal seismicity of Kamchatka. AGU Fall meeting. EOS Trans. AGU 85 (47) (Fall Meet. Suppl., Abstract T11D-1282).

Gorelchik, V.I., Garbuzova, V.T., Droznin, D.V., Levina, V.I., Firstov, P.P., Chubarova, O.S., Shirokov, V.A., 1995. The Shiveluch volcano: deep structure and prediction of eruptions using detailed seismicity data, 1962-1994. Volcanol. Seismol. 17, 423-448.

Gorshkov, G.S., 1959. Gigantic eruption of the volcano Bezymianny. Bull. Volcanol. 20, 77-109.

Gorshkov, G.S., 1963. Directed volcanic blasts. Bull. Volcanol. 26, 83-88.

Gorshkov, G.S., Bogoyavlenskaya, G.E., 1965. Bezymianny Volcano and Peculiarities of its Last Eruption (1955-1963). Nauka, Moscow (in Russian).

Gorshkov, G.S., Dubik, Yu.M., 1970. Gigantic directed blast at Shiveluch volcano (Kamchatka). Bull. Volcanol. 34, 261-288.

Guest, J.E., Sánchez, R.J., 1969. A large dacitic lava flow in northern Chile. Bull. Volcanol. 33, 778-790.

Hürlimann, M., Marti, J., Ledesma, A., 2000. Mechanical relationship between catastrophic volcanic landslides and caldera collapses. Geophys. Res. Lett. 27 (16), 2393-2396.

Ivanov, B.V., 1970. Eruption of Karymsky Volcano in 1962-1965 and Volcanoes of Karymsky group. Nauka, Moscow (in Russian).

Khubunaya, S.A., Zharinov, N.A., Muravyev, Ya.D., Ivanov, V.V., Boloyavlenskaya, G.E., Novgorodtseva, T.Yu., Demyanchuk, Yu.V., Budnikov, V.A., Fazlullin, S.M., 1995. 1993 eruption of Shiveluch volcano. Volcanol. Seismol. 17, 1-20.

Kozhurin, A.I., 2004. Active faulting at the Eurasian, North American and Pacific plates junction. Tectonophysics 380, 273-285.

Lagmay, A.M.F., van Wyk de Vries, B., Kerle, N., Pyle, D.M., 2000. Volcano instability induced by strike-slip faulting. Bull. Volcanol. 62, 331-346.

Leonov, V.L., 1995. Lineaments, tectonic fractures, and mechanical behaviour of Kliuchevskoi volcano. Volcanol. Seismol. 16, 627-648.

Leonov, V.L., 2003. Quaternary calderas of Kamchatka: overview, classification, structural position. Volcanol. Seismol. 2, 13-26 (in Russian).

Leonov, V.L., Grib, E.N., Kartasheva, L.A., 1990. On the structure and age of Taunshits volcano. Vopr. Geogr. Kamchatki 10, 156-166 (in Russian).

McGuire, W.J., 1996. Volcano instability: a review of contemporary themes. In: McGuire, W.J., Jones, A.P., Neuberg, J. (Eds.), Volcano Instability on the Earth and Other Planets. Geol. Soc. Special Publ., vol. 110, pp. 1-23.

Melekestsev, I.V., 1980. Volcanism and Relief Formation. Nauka, Moscow (in Russian).

Melekestsev, I.V., 2006. Large modern collapses on the active volcanoes of Kamchatka: causes and mechanisms of formation. In: Evans, S.G., Scarascia Mugnozza, G., Strom, A., Hermanns, R.L. (Eds.), Landslides Massive Rock Slope Failure: (NATO Science Series: IV: Earth and Environmental Sciences). Springer, pp. 439-453.

Melekestsev, I.V., Braitseva, O.A., 1984. Gigantic rockslide avalanches on volcanoes. Volcanol. Seismol. 4, 14-23 (English translation in Volcanol. Seismol., 6: 495-508, 1988).

Melekestsev, I.V., Braitseva, O.A., Erlich, E.N., Kozhemyaka, N.N., 1974. Volcanic mountains and plains. In: Luchitsky, I.V. (Ed.), Kamchatka, Kurile and Commander Islands. Nauka, Moscow, pp. 162-234 (in Russian).

Melekestsev, I.V., Volynets, O.N., Ermakov, V.A., Kirsanova, T.P., Masurenkov, Yu.P., 1991. Shiveluch volcano. In: Fedotov, S.A., Masurenkov, Yu.P. (Eds.), Active Volcanoes of Kamchatka, vol. 1. Nauka, Moscow, pp. 84-92. 
Melekestsev, I.V., Litasova, S.N., Sulerzhitsky, L.D., 1992. On the age and scale of the directed-blast catastrophic eruption of the Avachinsky volcano (Kamchatka) in the Late Pleistocene. Volcanol. Seismol. 13 (2), 135-146.

Melekestsev, I.V., Ponomareva, V.V., Volynets, O.N., 1995. Kizimen volcano (Kamchatka) - future Mt. St. Helens? J. Volcanol. Geotherm. Res. 65, 205-226.

Melekestsev, I.V., Dirksen, O.V., Girina, O.A., 1999. A giant landslide-explosion cirque and a debris avalanche at Bakening volcano, Kamchatka. Volcanol. Seismol. 20 (3), 265-280.

Newhall, C.G., Melson, W.G., 1983. Explosive activity associated with growth of volcanic domes. J. Volcanol. Geotherm. Res. 17, $111-131$

Ozerov, A.Yu., Demianchuk, Yu.V., 2004. Paroxysmal eruption of the Young Shiveluch volcano on May 10, 2004. Volcanol. Seismol. 5, 75-80 (in Russian).

Palmer, B.A., Alloway, B.V., Neall, V.E., 1991. Volcanic-debrisavalanche deposits in New Zealand - lithofacies organization in unconfined, wet-avalanche flows. In: Fisher, R.V., Smith, G.A. (Eds.), Sedimentation in Volcanic Settings. SEPM Spec. Publ., vol. 45, pp. 89-98.

Park, J., Levin, V., Lees, J., Peyton, V., Gordeev, E., Ozerov, A., 2002. A dangling slab, amplified arc volcanism, mantle flow and seismic anisotropy in the Kamchatka plate corner. In: Stein, S., Freymueller, J.T. (Eds.), Plate Boundary Zones. Geodynamics Series, vol. 30, doi:10.1029/030GD18.

Piip, B.I., 1956. Kliuchevskaya Sopka and Its Eruptions in 1944-1945 and the Past. Trans. Volc. Lab. AN SSSR, vol. 11 (in Russian).

Piip, B.I., Markhinin, E.K., 1965. Gigantic eruption of Shiveluch volcano on November 12, 1964 (preliminary report). Bull. Volcanol. Stancii 39, 3-28 (in Russian).

Ponomareva, V.V., 1990. The history of Krasheninnikov volcano and the dynamics of its activity. Volcanol. Seismol. 9, 714-741.

Ponomareva, V.V., Dirksen, O.V., Sulerzhitsky, L.D., 1995. Eruptive history of Dikiy Greben volcano - the largest Holocene extrusive edifice in Kamchatka, Russia. Abstracts Int. Workshop on Volcanoes Commemorating the 50th Anniversary of Mt. ShowaShinzan, p. 159.

Ponomareva, V.V., Pevzner, M.M., Melekestsev, I.V., 1998. Large debris avalanches and associated eruptions in the Holocene eruptive history of Shiveluch volcano, Kamchatka, Russia. Bull. Volcanol. 59 (7), 490-505.

Ponomareva, V.V., Sulerzhitsky, L.D., Dirksen, O.V., Zaretskaia, N.E., 2001. Holocene paleosols as records of intervals of volcanic quiescence in the Kurile Lake region, south Kamchatka, In: Juvigné, E., Raynal, J.P. (Eds.), "TEPHRAS, Chronology, Archaeology". Les dossiers de l'Archéo-Logie n ${ }^{\circ} 1$, CDERAD ed., pp. 91-100.

Ponomareva, V.V., Pevzner, M.M., Sulerzhitsky, L.D., 2002. Explosive activity of Shiveluch volcano, Kamchatka, during the last 10.000 years. Abstracts of the 3rd Biennial Workshop on Subduction Processes emphasizing the Kurile-Kamchatka-Aleutian Arcs. Fairbanks, USA.

Ponomareva, V.V., Kyle, P.R., Melekestsev, I.V., Rinkleff, P.G., Dirksen, O.V., Sulerzhitsky, L.D., Zaretskaia, N.E., Rourke, R., 2004. The $7600\left({ }^{14} \mathrm{C}\right)$ year BP Kurile Lake caldera-forming eruption, Kamchatka, Russia: stratigraphy and field relationships. J. Volcanol. Geotherm. Res 136, 199-222.
Reiche, P., 1937. The toreva block, a distinctive landslide type. J. Geol. 45 (5), 538-548.

Siebe, C., Komorowski, J.-C., Sheridan, M.F., 1992. Morphology and emplacement of an unusual debris-avalanche deposit at Jocotitlan volcano, central Mexico. Bull. Volcanol. 54, 573-589.

Siebert, L., 1984. Large volcanic debris avalanches: characteristics of source areas, deposits, and associated eruptions. J. Volcanol. Geotherm. Res. 22, 163-197.

Siebert, L., 1996. Hazards of large volcanic debris avalanches and associated eruptive phenomena. In: Scarpa, R., Tilling, R.I. (Eds.), Monitoring and Mitigation of Volcano Hazards. Springer, Berlin, pp. 541-572.

Siebert, L., Kimberley, P., Pullinger, C.R., 2004. The voluminous Acajutla debris avalanche from Santa Ana volcano, western El Salvador, and comparison with other Central American edificefailure events. In: Rose, W.I., Bommer, J.J., López, D.L., Carr, M.J., Major, J. (Eds.), Natural Hazards in El Salvador. Geol. Soc. Amer. Special Paper, vol. 375, pp. 5-23.

Simkin, T., Siebert, L., 1994. Volcanoes of the World, Second edition. Geoscience Press, Inc., Tucson, Arizona.

Tibaldi, A., 1996. Mutual influence of dyking and collapses, Stromboli volcano, Italy. In: McGuire, W.J., Jones, A.P., Neuberg, J. (Eds.), Volcano Instability on the Earth and Other Planets. Geol. Soc. Special Publ., vol. 110, pp. 55-63.

Vidal, N., Merle, O., 2000. Reactivation of basement faults beneath volcanoes: a new model of flank collapse. J. Volcanol. Geotherm. Res. 99, 9-26.

Voight, B., 2000. Structural stability of andesite volcanoes and lava domes. Philos. Trans. R. Soc. Lond., A 358, 1663-1703.

Voight, B., Glicken, H., Janda, R.J., Douglass, P.M., 1981. Catastrophic rockslide avalanche of May 18. In: Lipman, P.W. Mullineaux, D.R. (Eds.), The 1980 Eruptions of Mount St. Helens, Washington. US Geol. Surv. Prof. Pap., vol. 1250, pp. 347-378.

Volynets, O.N., Melekestsev, I.V., Ponomareva, V.V., Yogodzinski, J.M., 1999. Kharchinsky and Zarechnyi volcanoes — unique centers of Late Pleistocene magnesian basalts in Kamchatka: structural setting, morphology, geologic structure and age. Volcanol. Seismol. 20 (4-5), 383-400.

Wadge, G., Francis, P., Ramirez, C.F., 1995. The Socompa collapse and avalanche event. J. Volcanol. Geotherm. Res. 66, 309-336.

Waythomas, C.F., 2001. Formation and failure of volcanic debris dams in the Chakachatna River valley associated with eruptions of the Spurr volcanic complex, Alaska. Geomorphology 39, 111-129.

Yogodzinski, G.M., Lees, J.M., Churikova, T.G., Dorendorf, F., Woerner, G., Volynets, O.N., 2001. Geochemical evidence for the melting of subducting oceanic lithosphere at plate edges. Nature 409 (25), 500-504 (January).

Zharinov, N.A., Bogoyavlenskaya, G.E., Khubunaya, S.A., Demyanchuk, Yu.V., 1995. A new eruption cycle of Shiveluch volcano, 1980-1993. Volcanol. Seismol. 17, 21-30.

Zobin, V.M., Melekestsev, I.V., Shumilina, L.S., 1980. Detailed seismic zoning of region of high seismic activity in Kamchatka. In: Solonenko, V.P. (Ed.), Detailed Seismic Zoning. Nauka, Moscow (in Russian). 